\title{
Ćwiczenie czytania w języku obcym wspomagane komputerowo programem Colorado Literacy Tutor
}

\author{
Computer assisted reading tutoring in $\mathrm{L} 2$ \\ using Colorado Literacy Tutor
}

\author{
Konrad Juszczyk \\ Instytut Językoznawstwa, Uniwersytet im. Adama Mickiewicza \\ ul. Międzychodzka 5, 60-371 Poznań \\ Centrum Przetwarzania Mowy i Języka, Instytut Filologii Angielskiej \\ Uniwersytet im. Adama Mickiewicza, Collegium Novum \\ al. Niepodległości 4, 61-784 Poznań \\ juszczyk@amu.edu.pl
}

\begin{abstract}
Successful tutorship of reading depends on several conditions. Teaching to read require well prepared method with scientific foundations. Children expect entertaining exercises supported with motivational system and a patient tutor who helps in perfecting the skills related to reading. At last, the whole tutorship should be scalable, so large groups of children and whole schools can learn to read step by step. Their progress should be observable for teachers, parents and researchers. Computer assisted reading tutoring may fulfill all these conditions. Colorado Literacy Tutor is a program especially designed to meet these expectations and this article is to explore its possibilities. Short report on pioneer testing of $C L T$ on Polish children is also given.
\end{abstract}

\section{Warunki dobrego nauczania czytania}

Nauka czytania wymaga starannie wypracowanych metod kształcenia umiejętności czytelniczych. Rozpoczęta odpowiednio wcześnie i prowadzona z należytą konsekwencją sprawi, że dziecko nauczy się czytać płynnie i będzie czytało chętnie i z zaciekawieniem. Prawidłowe opanowanie umiejętności i zwyczajów związanych z czytaniem jest warunkiem koniecznym w zdobywaniu wiedzy i wykształcenia. Współczesne społeczeństwa i gospodarka są zależne od dostępu do informacji i zdolności ich przetwarzania. Najwyższy stopień alfabetyzacji i czytelnictwa idzie w parze z wysokim wskaźnikiem rozwoju gospodarczego - produktem krajowym brutto. ${ }^{1}$ Wg badań OECD (Pont and Werquin 2000) związki pomiędzy czytelnictwem a rozwojem ekonomicznym są liczne i oczywiste.

\footnotetext{
${ }^{1}$ Wg danych opartych na CIA Factbook i wykresie korelacji alfabetyzacji i PKB dostępnym w serwisie internetowym Index Mundi pod adresem: http://www.indexmundi.com/g/correlation.aspx?v1=67\&v2=39\&y=2003
} 
Co więcej, obok czytania, do umiejętności jakie dziś uznaje się za niezbędne dla pełnego funkcjonowania $\mathrm{w}$ społeczeństwie zalicza się także zdolności do organizowania zdobytych treści, podstawowe działania arytmetyczne i gotowość do uczenia się nowych sposobów pozyskiwania wiedzy ${ }^{2}$. Rewolucja informatyczna, jakiej jesteśmy świadkami i mimowolnymi uczestnikami wprowadza coraz to nowsze media, wymagając od użytkowników coraz większej samodzielności, uczenia się ich obsługi i przyzwyczajania się do kontaktu człowiek-media oraz człowiek-media-człowiek.

Obowiązkowa nauka czytania w Polsce zaczyna się już w przedszkolu, w najstarszych grupach wiekowych. W szkole podstawowej ćwiczenia czytania są prowadzone $\mathrm{w}$ ramach nauczania zintegrowanego w klasach I-III, a od IV klasy w ramach lekcji języka polskiego. Język obcy wprowadza się obowiązkowo od IV klasy. We wcześniejszych klasach angielski jest nauczany w $2 / 3$ szkół podstawowych. Wprowadzenie angielskiego jako obowiązkowego od pierwszej klasy zaplanowano na rok 2008. Od klasy IV będzie wówczas prowadzona nauka drugiego języka obcego $^{3}$. Tak ustalony program nauczania sprawia, że dzieci są nauczane czytania $\mathrm{w}$ języku rodzimym (polskim) i obcym (angielskim) prawie (w większości przypadkach) równolegle. Ponieważ ortografia tych języków różni się znacznie głębokością (por. niżej), więc nauczanie czytania powinno być prowadzone $\mathrm{z}$ należytą ostrożnością. Trudności wynikające $\mathrm{z}$ różnic $\mathrm{w}$ systemach zapisu $\mathrm{w}$ języku obcym i rodzimym nie powinny zniechęcać do nauki. W przezwyciężeniu tych trudności mogą pomóc dodatkowe zajęcia językowe - ćwiczenia czytania wspomagane komputerowo. Niniejszy artykuł przedstawia wybrane ćwiczenia programu Colorado Literacy Tutor i wyniki badań przeprowadzonych przez autora wśród polskich dzieci uczących się angielskiego od I klasy szkoły podstawowej.

Skuteczne nauczanie czytania zależy od szeregu warunków. Proces nauczania wymaga odpowiednio dobranych i popartych naukowo metod. Dzieci oczekują atrakcyjnych ćwiczeń i zachęcania do ich wykonania przez system nagród. Nad przebiegiem nauki czytania powinien czuwać nauczyciel, który cierpliwie objaśnia i kontroluje postępy dziecka, jednocześnie dając mu szansę na samodzielną naukę. Wreszcie system nauczania powinien być zorganizowany tak, by mógł obejmować duże grupy dzieci i całe szkoły, a postępy dzieci mogły być monitorowane zarówno przez kierujących szkołą, jak i rodziców, a także przez prowadzących badania dydaktyczne. Nauczanie czytania wspomagane komputerowo programem Colorado Literacy Tutor spełnia wymienione warunki, wprowadzając jednocześnie wiele nowoczesnych rozwiązań.

\section{Organizacja procesu nauczania czytania za pomocą $C L T$}

Colorado Literacy Tutor ${ }^{4}$ można określić jako elementarz XXI wieku. Charakterystykę CLT na tle tradycyjnych elementarzy drukowanych i programów komputerowych (w tym także polskich) już wstępnie przedstawiono (Juszczyk 2005), dlatego tu zostaną powtórzone tylko najważniejsze cechy CLT. Program został stworzony przez Center for Speech and Language Research $^{5}$ (CSLR) na Uniwersytecie Stanu Kolorado w Boulder (USA), a do badań został udostępniony dzięki współpracy $\operatorname{CSLP} P^{6} \mathrm{z} C S L R$.

\subsection{Metoda nauczania czytania w $C L T$}

Seria ćwiczeń językowych w programie $C L T$ została ułożona przez zespół badaczy CSLR. Ćwiczenia noszą nazwę Tutors, a artykułach CSLR - Foundational Reading Exercises (FRE) (Wise [w druku]). Kierownik zespołu - Barbara Wise - opracowała wcześniej zbiór ćwiczeń Linguistic Remedies. Ćwiczenia te mają na celu doskonalenie zdolności głównie związanych z czytaniem, takich jak dekodowanie fonologiczne (phonological decoding), pamięć i świadomość fonologiczna

\footnotetext{
${ }^{2}$ Wymienione umiejętności są w zakresie oznaczania angielskiego terminu literacy.

${ }^{3}$ Dane na podstawie działu aktualności na stronie www Ministerstwa Edukacji Narodowej: www.men.waw.pl/oswiata/biezace/j_angielski.php

${ }^{4}$ Oficjalna strona programu: http://www.colit.org/

${ }^{5}$ Oficjalna strona internetowa: http://cslr.colorado.edu

${ }^{6}$ Center for Speech and Language Processing czyli Centrum Przetwarzania Mowy i Języka Uniwersytetu im. Adama Mickiewicza w Poznaniu, oficjalna strona centrum: http://ifa.amu.edu.pl/ cslp/
} 
(phonological memory and phonological awareness), literowanie (spelling) i szybkie nazywanie (rapid naming issues). Adresatami ćwiczeń są dzieci uczące się czytać, a zwłaszcza mające specyficzne trudności w czytaniu ${ }^{7}$ (Specific Reading Disabilities) oraz dzieci z dysleksją.

Podstawą ćwiczeń jest Prosty model czytania (Simple Model of Reading) Gough'a i Tunmer'a (Wise [w druku]). Zgodnie $\mathrm{z}$ tym modelem czytanie to ciągłe dekodowanie, a potem rozpoznawanie wyrazów w celu zrozumienia tekstu. Zakłada się, że w procesie czytania rolę decydującą odgrywa analiza fonologiczna, czyli metoda foniczna (phonics) zwana też alfabetyczną (w przeciwieństwie do globalnej czy całościowej). Ponieważ rozwój świadomości fonologicznej wspomaga naukę czytania, liczne powtórzenia ćwiczeń przy odpowiednim instruktażu mają prowadzić do wyuczenia odpowiednich nawyków i zapewnić płynne czytanie. Analiza fonologiczna jest konieczna w nauce czytania w języku angielskim, którego ortografię określa się jako głęboką (Kamińska 1999). Oznacza to, że związki i reguły grafo-fonemiczne są złożone i liczne, pisownia wielu wyrazów jest nieregularna, wiele głosek ma zbieżne odpowiedniki literowe. Na przykład: głoski /s/ i /z/ są zapisywane literą $s$ zależnie od pozycji w wyrazie: sit albo has lub głoski /tø/ i / / są zapisywane literami ch zależnie od pozycji w wyrazie: church albo machine (dokładne omówienie zasad odpowiedniości głosek i liter w języku angielskim przedstawia Hall (Hall 1966).

Obecnie można zaobserwować działania mające na celu zwrócenie uwagi na kształcenie świadomości fonologicznej w nauce czytania w języku angielskim. Rewizja metod nauczania czytania w Wielkiej Brytanii na przykład sprawiła, że brytyjski rząd zaleca stosowanie metody fonicznej (phonics) obowiązkowo we wszystkich szkołach od początku 2006 roku (Smith 2006). Wśród metod nauki czytania w języku polskim, jako opierającą się na analizie fonicznej należy wyróżnić metodę Rocławskiego. Metoda ta zwana jest fonetyczno-literową-barwną, gdyż polega na układaniu wyrazów i krótkich tekstów za pomocą klocków (nazwanych $L O G O$ ) z kolorowymi literami. Zabawa klockami służy uwrażliwieniu na związki między literą a głoską, a także doskonaleniu percepcji i pamięci wzrokowej oraz interakcji z dziećmi w grupie (Rocławski [brak]).

\subsection{Atrakcyjna forma ćwiczeń}

Dzieci najchętniej uczą się przez zabawę, dlatego ćwiczenia czytania w CLT mają formę gier obrazkowo-językowych. Wykonywanie ćwiczeń opiera się na kojarzeniu obrazków przedmiotów z ich nazwami w postaci dźwiękowej (nagranie może być odtwarzane dowolną liczbę razy) lub literowej. Trudniejsze ćwiczenia wymagają połączenia części wyrazów (sylab lub ich części oraz pojedynczych liter) w celu ułożenia podpisu pod obrazkiem. Ćwiczenia doskonalą przy okazji spostrzegawczość, refleks, koncentrację i uwagę. Najważniejszą jednak zaletą ćwiczeń jest możliwość sprawdzenia się. Dzięki instruktażowi dzieci są zachęcane do wykonania ćwiczenia zgodnie $\mathrm{z}$ określonymi zasadami. Cele i warunki wykonania ćwiczeń językowych ściśle wyznaczone przez program pozwalają na testowanie hipotez metajęzykowych dotyczących relacji głoska-litera itp.

Multimedialna forma gry sprawia, że dziecko chętnie rozwiązuje zadanie przez odpowiednią interakcję z komputerem i steruje nim za pomocą myszki. Plansza (interfejs) gry wyznacza możliwe ruchy (posunięcia $\mathrm{w}$ grze) dziecka skupiając jego uwagę na ograniczonej liczbie elementów - paru przyciskach, obrazkach czy ramkach z literami. Całość oddziałuje na wiele zmysłów jednocześnie - głównie wzrok i słuch dziecka, co ma zintensyfikować kojarzenie głosek z literami i słyszanych nazw przedmiotów $\mathrm{z}$ ich obrazkami. Dodatkowym atutem gier jest animowana i mówiąca ludzkim głosem postać Wirtualnej Nauczycielki, o której więcej poniżej.

Każda próba rozwiązania zadania jest symbolicznie nagradzana. Autorzy programu założyli, że należy doceniać wszelkie wysiłki dziecka. Nawet, jeśli zadanie nie zostało wykonane w zupełności poprawnie, ważne jest to, że dziecko poświęciło mu swoją uwagę, czas i wytrwało do końca. Zdobyte doświadczenia na pewno wykorzysta w następnej próbie.

\footnotetext{
${ }^{7}$ Termin specyficzne trudności w czytaniu celowo nawiązuje do określenia wprowadzonego przez Bogdanowicz: uczniowie ze specyficznymi trudnościami w czytaniu i pisaniu (Bogdanowicz 2005)
} 
Nagroda jest wirtualna. Po zakończeniu ćwiczenia na ekranie ukazuje się prezent (pudełko przewiązane wstążką), z którego po kliknięciu nań wyskakuje drobny upominek, najczęściej zabawka. Jak wynika $\mathrm{z}$ obserwacji autora artykułu, taka forma nagradzania dzieci bardzo cieszy, mimo że nie dostają one żadnych materialnych prezentów. Wirtualne zabawki przynoszą radość, ponieważ współczesne dzieci samo obcowanie $\mathrm{z}$ komputerem traktują jako frajdę, a programy edukacyjne przypominają im popularne gry komputerowe.

\subsection{Rola Wirtualnej Nauczycielki}

Nad przebiegiem ćwiczenia czuwa Wirtualna Nauczycielka (w skrócie WN) w postaci gadającej głowy o twarzy młodej kobiety. Stosowane coraz częściej w komunikacji człowiek-komputer wirtualne imitacje ludzi są nazywane awatarami lub agentami ${ }^{8}$. Postać WN jest trójwymiarowa i płynnie animowana. Do wyboru są także inne wcielenia WN, różniące się płcią, wiekiem i rasą, gdyż program ma służyć różnym grupom wiekowym i etnicznym w Stanach Zjednoczonych i na świecie. Prace nad różnojęzycznymi wersjami programu, w tym polską, już trwają (Dziubalska-Kołaczyk et al. 2006). WN wypowiada polecenia, thumaczy dziecku, co zrobić w danym ćwiczeniu - gdzie i w jakim celu klikać. Charakterystykę WN przedstawiono już wcześniej (Wise [w druku]; Juszczyk 2005). Wynika z niej jasno, że animowana postać o imieniu Marni ma zastępować realną nauczycielkę. Autorzy dołożyli wielu starań by, korzystając z najnowszych technologii, $W N$ sprawiała wrażenie realnie towarzyszącej dziecku nauczycielki. Obecność takiego awatara ma ułatwiać interakcję z komputerem. Jej komunikaty zachęcają do kolejnych kroków w wykonywanym ćwiczeniu i cierpliwie opisują popełnione błędy. Nagrania naturalnego głosu (zamiast wciąż niedoskonale brzmiącej syntezy mowy) są skorelowane z ruchami ust awatara, dzięki czemu uczą poprawnej wymowy. Dają także szansę na osłuchanie się z językiem (obcym dla naszych polskich dzieci), tak ważne na początkowym etapie jego nauki (Pamuła 2003).

Przykładowe wypowiedzi Marni to: Welcome to the Matching Game!; Find the two pictures that match.; Click on arrow to continue oraz czytanie wybranych przez dziecko liter i wyrazów. Opis dialogu polskiego dziecka z awatarem zawarto już w poprzednim artykule autora o CLT (Juszczyk 2005). W przywołanym dialogu występuje także postać eksperymentatora (prowadzącego badania autora artykułów), który asystował na początku wykonywanych ćwiczeń. Jednakże udział eksperymentatora przy kolejnych próbach zmniejszał się i ograniczał tylko do przypadków awaryjnych, gdy program lub komputer nie reagował w ogóle na żadne działania dziecka (co niestety zdarzało się dość często, gdyż program $C L T$ jest jeszcze w fazie testów). Zgodnie z założeniami autorów programu CLT dziecko ma „samodzielnie” korzystać z programu, a $W N$ ma aktywnie wspomagać wykonywanie zadań i sprawiać, że dziecko czuje się pewniej.

\subsection{Kontrola za pomocą Managed Learning Environment (MLE)}

Program CLT to pokaźny pakiet aplikacji edukacyjnych służących głównie nauce i doskonaleniu czytania, a także, potencjalnie, prezentacji wiedzy z rozmaitych przedmiotów w ramach kształcenia podstawowego. System został tak zaprojektowany, by możliwy był podgląd postępów czynionych przez uczące się dzieci w poszczególnych grupach, klasach i szkołach. Każdy uczeń może mieć założone własne konto. Dzięki temu uczeń nie jest „przywiązany” do danego komputera, lecz może skorzystać z dowolnego dostępnego komputera w szkole i mieć z niego dostęp do swojego profilu. Do konta są przypisane ćwiczenia lub odpowiedni plan nauczania (Automatic Study Plan). Dziecko zaczyna sesję ćwiczeń od zalogowania się do swojego konta (konto może być zabezpieczone hasłem) i wyboru dla niego przeznaczonych ćwiczeń. Przy czym wybór ćwiczeń jest ograniczony i narzucony przez program, zależnie od postępów i wyników danego dziecka. Wyniki ćwiczeń są rejestrowane i przesyłane na osobny komputer - serwer podłączony przez sieć internetową.

Dzięki MLE grupa dzieci ćwicząca czytanie może być monitorowana zdalnie, a wyniki poszczególnych dzieci porównywane na stronie www. Nauczyciele mogą sprawdzać, jak uczą się wybrani uczniowie i, jeśli trzeba, zadawać dodatkowe ćwiczenia. Pedagodzy mogą nadzorować

\footnotetext{
${ }^{8}$ Przegląd awatarów itp.: http://www.fizyka.umk.pl/ duch/IR.html\#Agent
} 
proces kształcenia, by w porę zauważyć, które z dzieci ma szczególne problemy z czytaniem i nauką, a zwłaszcza wyławiać dzieci z dysleksją. Rodzice mają także możliwość zobaczenia jak radzą sobie ich pociechy. I wreszcie naukowcy chcący badać skuteczność wybranych ćwiczeń i metod mają pełen podgląd w postaci tabel, wykresów i raportów na stronie www. Fragmenty takich raportów prezentuje niniejszy artykuł.

\section{Charakterystyka badanych dzieci}

Grupa dzieci biorących udział w testach CLT w Polsce została wybrana ze szkoły podstawowej, w której nauka angielskiego zaczyna się już w pierwszej klasie. W badaniu wzięło udział 25 dzieci, z czego 14 z klasy pierwszej i 11 z klasy drugiej. Proporcja dziewczynek do chłopców wynosi 7:7 w pierwszej klasie i 5:6 w drugiej. Mała liczba dzieci wynika z ograniczeń technicznych, a dobór dzieci był zależny od zgody ich nauczycieli i rodziców, od których uzyskano pisemną zgodę na przeprowadzenie badań. Zgody na badania udzieliła także dyrektor szkoły.

Szczegółowy opis ćwiczeń w niniejszym artykule opiera się na badaniu pierwszej grupy dzieci - z pierwszej klasy szkoły podstawowej. Do opisu wybrano ćwiczenie Matching, gdyż wykonała je większość dzieci. Naturalnie wiele cech ćwiczenia Matching dotyczy także innych ćwiczeń CLT, a opisywane ćwiczenie można uznać za modelowe.

\subsection{Przygotowanie dzieci do obsługi komputera}

Dzieci biorące udział w badaniach należą do pokolenia, dla którego komputer stanowi już rzecz oczywistą. Większość z nich (wg wywiadów autora - prawie wszystkie) ma komputer w domu, własny lub rodziców i często z niego korzysta. Pytane o to, co robią na komputerze z łatwością wymieniały popularne gry komputerowe lub programy edukacyjne. Niektórzy chłopcy opowiadali nawet jak wspólnie z ojcem obstawiają wyniki meczów na stronie buchmacherskiej (sic!) lub licytują na aukcjach w serwisie Allegro (sic!). Należy pamiętać, że jeszcze parę lat temu komputer i Internet w Polsce stanowił rzadkość nawet dla starszych dzieci i dorosłych. Przygotowanie dzieci do obsługi komputera ułatwia prowadzenie badań nad edukacją multimedialną. Żadnemu z dzieci nie trzeba było thumaczyć, do czego służy myszka i jak się nią posługiwać. Ćwiczenia wybrane do testów nie wymagają używania klawiatury, CLT w tych ćwiczeniach w ogóle nie reaguje na naciskanie klawiszy klawiatury. Wszelkie próby naciskania klawiszy przez dzieci spotykały się z prośbą eksperymentatora o korzystanie tylko z myszki. Wykonywanie ćwiczeń polega głównie na poruszaniu kursorem na ekranie i klikaniu jednym z przycisków (lewy i prawy przycisk myszy mają w $C L T$ tę samą funkcję) w wybrane miejsca na ekranie. Dzieci pojmowały to bardzo szybko, o pomoc prosiły w sporadycznych przypadkach.

\subsection{Obserwacje poczynione podczas badań}

Zainteresowanie samym komputerem jest wśród dzieci ogromne, dlatego większość dzieci chętnie brała udział $\mathrm{w}$ badaniach i entuzjastycznie reagowała w interakcji z Marni. Między badaniami zaobserwowano, jak dzieci często wypytywały się nawzajem o to, jakie ćwiczenia robiły, ile zdobyły punktów, jakie otrzymały nagrody itp.

\subsubsection{Zainteresowanie sprzętem}

Niektóre chciały dowiedzieć się czegoś więcej o komputerze. Pytały o to, co się stanie, kiedy nacisną na przycisk na klawiaturze. Eksperymentator z reguły pozwalał, by dziecko samo się przekonało, że $C L T$ nie reaguje na naciskanie klawiszy klawiatury. Pytały też m.in. o znaczenie świecących „lampek” czyli diod sygnalizujących poziom naładowania baterii w komputerze lub fakt podłączenia do sieci komputerowej itp. Wówczas starano się zwrócić uwagę na ekran komputera, gdzie Marni oczekiwała kolejnych kroków w rozwiązywanym zadaniu. Celem badań było przede wszystkim przeprowadzenie dzieci przez kolejne ćwiczenia, a nie zapoznawanie z całym oprzyrządowaniem. Stąd na pytania o to, czy komputer jest podłączony do Internetu (dosłownie: a czy tu jest Internet?) i czy są zainstalowane inne gry eksperymentator był zmuszony odpowiadać przecząco. Gdyby potwierdził, niejedno dziecko zapytałoby, czemu nie może z Internetu skorzystać itd. 


\subsubsection{Uwaga i koncentracja dzieci na wykonywanych zadaniach}

Uwaga dzieci wczesnoszkolnych jest rozproszona i niejednolita. Jeśli mają poczucie, że „dobrze im idzie” i „dobrze się bawią", potrafią się skoncentrować na danym im zadaniu by wykonać je do końca. Jeśli jednak zadanie jest zbyt proste, dzieci okazują oznaki znudzenia i pytają eksperymentatora ile jeszcze ćwiczenia potrwają. Wtedy proszono o ukończenie zadania czyli przejście przez wszystkie etapy (przykłady), bo dopiero potem CLT zadawał następne ćwiczenie. Jeśli dziecko zgłaszało, że ma już dość, sesję przerywano.

Zdarzało się także, że zadanie okazywało się wyjątkowo trudne i dziecko nie wiedziało, co zrobić (gdzie i w jakim celu klikać). Wówczas przypominano, że można klikać „gdziekolwiek” na ekranie, a Marni wyjaśni czy dana odpowiedź była prawidłowa czy błędna. Program CLT jest tak skonstruowany, by do rozwiązania zadania można było dojść metodą prób i porażek, przez cierpliwe eksperymentowanie i słuchanie reakcji Wirtualnej Nauczycielki oraz obserwowanie zmian na ekranie. W ukończeniu zadania pomaga liczenie punktów (monety), jakie dzieci otrzymują za kolejne etapy (przykłady wyrazów), a także świadomość, że za ukończone zadanie zawsze dostaną nagrodę.

Kwestia utrzymania skupienia uwagi dziecka w ćwiczeniach językowych jest bardzo istotna. Dzieci wczesnoszkolne są gotowe do nauki, lecz nie są tego świadome i traktują naukę jako zabawę. Łatwiej przekonać je do „zagrania” niż wykonania danego ćwiczenia na ekranie. Interakcję z komputerem kojarzą raczej z grami komputerowymi i czasem wolnym, a nie z nauką. Dlatego ciągła obecność Wirtualnej Nauczycielki jest ogromną zaletą programu. Marni spełnia rolę strażnika uwagi dziecka. Awatar jest tak zaprogramowany, by dziecko miało wrażenie, że jest obserwowane. Marni porusza głową, mruga oczami, a po dhuższej bezczynności ucznia (braku klikania myszką) Marni uśmiecha się, tak jakby chciała zachęcić ucznia do dania odpowiedzi (kliknięcia na literę lub słowo czy obrazek). Autorzy programu zapowiadają, że wkrótce Marni będzie mogła wodzić wzrokiem za uczniem, by zawsze utrzymać z nim kontakt wzrokowy; a jeśli uczeń odszedłby od komputera, Marni mogłaby go upomnieć i zawołać (Wise [w druku]). Wystarczy zamontować kamerę i odpowiednio zaprogramować CLT by Wirtualna Nauczycielka jeszcze bardziej naśladowała realną nauczycielkę.

\subsubsection{Reakcje na komunikaty głosowe i inne zachowania Marni}

Program $C L T$ komunikuje się z użytkownikiem dwoma kanałami: wizualnym (ekran) i słuchowym (słowne komunikaty Marni). Uczeń widzi na ekranie przyciski, krótkie napisy (OK, EXIT, Again i Help) i ikony, na które może klikać. Wszelkie inne działania użytkownika nie zostaną przez program zauważone. Każde kliknięcie, zwłaszcza w polu wykonywanego zadania (kliknięcie na literę lub wyraz czy obrazek) wywołuje reakcję słowną Marni. Taka forma dialogu dziecka z komputerem jest asychroniczna, więc tylko częściowo przypomina interakcję dziecka z realnym nauczycielem. O Marni można powiedzieć, że mówi do dziecka, lecz jeszcze go nie słyszy i nie rozumie słownych odpowiedzi dziecka. Jednakże prace nad tym, by program rozpoznawał mowę podczas ćwiczeń (Tutors) już trwają. Seria książeczek interaktywnych (Interactive Books) umożliwia dziecku odczytanie tekstu (podanego na ekranie) w języku angielskim. Program CLT ma zaimplementowane rozpoznawanie mowy firmy SONIC, ale nie jest jeszcze przystosowany do polskiej mowy dziecięcej. Działania w kierunku ,spolszczania” platformy CLT podjęto w ramach projektu PELT ${ }^{9}$ w $C S L P^{I 0}$ w Poznaniu (Dziubalska-Kołaczyk et al. 2006; Bogacka et al. 2006).

Wszystkie komunikaty słowne Marni w testowanej wersji $C L T$ są wydawane w języku angielskim. Dzieci biorące udział w badaniach w większości uczą się angielskiego od początku szkoły podstawowej (badania prowadzono pod koniec roku szkolnego), a niektóre zaczęły naukę już w przedszkolu. Rok czy dwa lata nauczania początkowego języka angielskiego ma na celu osłuchanie się z językiem i zapoznanie z podstawowym słownictwem. Nie wystarcza jednak by dzieci rozumiały dokładnie to, co mówiła do nich Wirtualna Nauczycielka. Po pierwsze raczej nie znają wielu słów wypowiadanych przez Marni w takich komunikatach jak Welcome to the

\footnotetext{
${ }^{9}$ Polish-English Literacy Tutor: http://ifa.amu.edu.pl/ cslp/plt_e.html

${ }^{10}$ Center for Speech and Language Processing: http://ifa.amu.edu.pl/ cslp/index.html
} 
Matching Game czy Click on arrow to continue lub Choose the letter that says $f$. Po drugie nie są przyzwyczajone do nauczycielki mówiącej tylko i wyłącznie po angielsku. Mimo to, interakcja z komputerem przebiegała sprawnie. Niezrozumienie komunikatów nie było dla dzieci przeszkodą, gdyż wykonanie ćwiczenia językowego to dla nich gra, której reguły (sposób postępowania) odkrywały przez eksperymentowanie. Można zakładać, że dzieci rozumiały komunikaty w stopniu minimalnym, wystarczającym by wykonać ćwiczenie. Najczęściej kojarzyły dany komunikat z sytuacją zaistniałą na ekranie. Wypowiedź Welcome to the Matching Game pada na początku ćwiczenia i dzieci wiedziały, że rozpoczyna się nowe ćwiczenie z nową „planszą" do gry. Wypowiedź Click on arrow to continue pada po skończeniu zadania, po którym wybiera się następne. Jeśli dane dziecko nie wiedziało co zrobić po skończeniu zadania, eksperymentator podpowiadał by kliknęły na strzałkę. To jednak zdarzało się rzadko i tylko na początku badań. Trzecia z przytoczonych wypowiedzi: Choose the letter that says $f$ pochodzi z ćwiczenia zwanego Letters-Sounds 4 square, gdzie zadaniem dziecka jest wybieranie jednej z czterech liter na ekranie. W większości przypadków reakcją na taki komunikat było kliknięcie na jedno z czterech pól z literą. Kliknięcie powoduje wymówienie (przez Marni) głoski oznaczanej przez daną literę. Komunikat może więc zawierać słowa, których znaczenie nie jest dzieciom dokładnie znane (choose itd.), ale o funkcji, o znaczeniu całościowym komunikatu dzieci łatwo się przekonują w toku interakcji. Dodatkowo na ekranie w każdym ćwiczeniu jest przycisk Again, którego kliknięcie powoduje ponowne podanie polecenia lub samej głoski czy wyrazu.

\subsection{Techniczne kwestie badań}

Badania prowadzono na terenie szkoły w specjalnie przygotowanej do tego sali komputerowej, z każdym dzieckiem indywidualnie. Testy wykonano na komputerze przenośnym podłączonym do sieci internetowej. Komputer był wyposażony w myszkę na podkładce i parę głośników, by głos awatara CLT - Marni był wyraźny i donośny. Nie zastosowano słuchawek, gdyż prowadzący badania także musiał słuchać Marni i kontrolować przebieg testów.

\section{Opis wybranych do badań ćwiczeń CLT typu Matching}

Ćwiczącym w programie CLT założono konta, do których przypisano zestawy ćwiczeń (Automatic Study Plan). Uczniowie mogą mieć ustalony stopień (Grade Level). Dla uczniów klasy pierwszej ustalono stopień pierwszy (w CLT jest to stopień K), a dla uczniów klasy drugiej - drugi (w CLT jest to stopień 1). Nad przebiegiem wykonywanych ćwiczeń czuwa system Managed Learning Environment, który zadaje uczniom kolejne ćwiczenia zależnie od ich postępów. System ten decyduje o tym, jakie ćwiczenia pominąć, a jakie powtórzyć oraz na jakim poziomie (Level) dane ćwiczenie powinno być zadane. Ponadto wyróżnia się także tryb (Type) wykonania ćwiczenia: Practice, Memory, Test i Speedy. W pierwszych dwóch trybach czas wykonania zadania nie jest ograniczony, a w następnych dwóch na ekranie pokazana jest skala czasu obrazująca upływ czasu. Jednakże w każdym z trybów czas spędzony na wykonanie danego zadania jest mierzony. Ponadto program rejestruje liczbę poprawnych odpowiedzi i liczbę kroków wykonanych przez dziecko w danym ćwiczeniu. Dane o czasie wykonania zadania oraz liczbie zdobytych punktów są wysyłane do serwera, z którego uzyskuje się podsumowania ćwiczeń w postaci tabeli na stronie www. Dostęp do danych jest ograniczony i chroniony hasłem, każdy z użytkowników (rodzic, nauczyciel czy badający) musi mieć swoje konto. Tabele prezentowane poniżej zostały wygenerowane przez skrypty strony $M L E$, a następnie przystosowane do niniejszej publikacji przez autora artykułu. ${ }^{11}$

\footnotetext{
${ }^{11} \mathrm{~W}$ artykule nie podaje się adresu strony $M L E$, gdyż nie jest to strona ogólnie dostępna. Twórcą tabel jest $C S L R$, a autor niniejszego artykułu wybrał tabele dotyczące przeprowadzonych badań i przystosował je tylko do celów naukowych i publikacyjnych.
} 


\subsection{Cele ćwiczenia}

Ćwiczenie typu Matching jest jednym z pierwszych ćwiczeń zadawanych swoim uczniom przez program CLT. Celem ćwiczeń jest wykształcenie skojarzeń formą pisaną a nie dźwiękową. Stanowi to wstęp do nauki czytania, w której ,warunkiem powodzenia w opanowaniu mapy alfabetycznej jest uchwycenie odpowiedniości liter i dźwięków" (Wolf, Vellutino, and Gleason 2005). Badania referowane przez Wolf i innych dowiodły, że „szybkość nazywania liter była silnym predykatorem późniejszej umiejętności czytania, zwłaszcza rozpoznawania słów” (Wolf, Vellutino, and Gleason 2005).

Ponadto czynność czytania wymaga od dziecka odpowiednio wytrenowania uwagi i pamięci, zwłaszcza wzrokowej. Wszelkie ćwiczenia komputerowe prezentują określone bodźce językowe obok bodźców niezwiązanych z językiem, choć również znaczących: ilustracji i przycisków. Nauka czytania wspomagana komputerowo rozwija u dziecka wybiórcze kierowanie uwagi konieczne przy odróżnianie elementów językowych od siebie, a także od innych, niezwiązanych z językiem. Według Gibson, nauka czytania opiera się na przetwarzaniu nazwanym przez nią uczeniem się percepcyjnym. Polega ono $\mathrm{w}$ dużej mierze na rozróżnianiu wymiarów zmiennych i stałych, by skuteczniej poszukiwać tych niezmiennych (Wolf, Vellutino, and Gleason 2005).

Istotnym celem ćwiczenia w programie $C L T$ jest także doskonalenie umiejętności związanych z używaniem samego narzędzia badań - komputera. W szczególności chodzi o koordynację ruchową, motorykę ręki poruszającej myszkę. Podstawę obsługi komputera stanowi zasada point\&click ${ }^{12}$ czyli wskaż i kliknij. Następnie konieczna jest obserwacja skutków klikania widocznych w postaci zmian na ekranie i słyszanych w dialogu z Wirtualna Nauczycielka. Ważne jest by dzieci czuły, że mają wpływ na to, co się dzieje na ekranie w programie. Interfejs ćwiczeń został tak zaprojektowany, by nauka wspomagana komputerem w najwyższym stopniu przypominała interakcję dziecko-nauczyciel. Dzięki temu uczącym się łatwiej będzie nawiązać kontakt z maszyną, która wedle teorii Reeves'a i Nass'a staje się naszym nowym partnerem interakcji symbolicznej (Reeves and Nass 2000).

Wreszcie ćwiczenia czytania wspomagane komputerem pomagają w zmianie nastawienia dzieci do nauki i komputera. Dla większości dzieci jest to już znana zabawka, ale o jej możliwościach dopiero się przekonują. Interakcja z rozbudowanym programem edukacyjnym jakim jest $C L T$ daje dzieciom - przyzwyczajonym do traktowania komputera jako źródła rozrywki szansę na poznanie komputera jako nowego narzędzia do nauki. I nie muszą sobie być tej przemiany świadome. Na pewno docenią to później, kiedy (być może już wkrótce) komputer będzie w każdej sali lekcyjnej.

\subsection{Interfejs ćwiczenia}

$\mathrm{Na}$ poniższym zrzucie (kopii zawartości ekranu programu) widzimy interfejs ćwiczenia: imię i nazwisko ucznia ${ }^{13}$, zegar, a pod nim planszę gry, obok niej $W N$, a pod nią ponownie imię ucznia i licznik punktów. Pod planszą gry znajduje się nazwa ćwiczenia (tu zmieniona, co powinno być również poprawione przez autorów programów) i przyciski z napisami WYJŚCIE (EXIT) i POMOC (HELP) oraz NASTĘPNY (NEXT, chwilowo nieaktywny). Wymienione elementy ekranu stanowią stałą część intefejsu ćwiczeń CLT (Tutors).

Warto zauważyć, jak dużą powierzchnię ekranu zajmuje plansza gry, stanowi ona blisko połowę jego powierzchni. Twarz Wirtualnej Nauczycielki zajmuje około $1 / 7$ ekranu i jest jedyną animowaną częścią gry. Umieszczona zawsze po prawej stronie nie przeszkadza w grze, ale nie trudno ją zauważyć. Podobnie - karty zajmują ponad 1/3 ekranu, gdyż są najważniejsze w grze i mają przyciągać uwagę ucznia. Każda z 6 kart po najechaniu nań kursorem myszki podświetla się, co ma sugerować, że należy na nią kliknąć. Przyciski aktywują się tylko wtedy, gdy można na nie kliknąć, co eliminuje zbędne ruchy dziecka i nie odwraca uwagi od wykonywanego ćwiczenia.

\footnotetext{
${ }^{12}$ Omówienie zasady na stronach wikipedii: http://en.wikipedia.org/wiki/Point-and-click

${ }^{13}$ Widoczne na obrazku imię i nazwisko jest zupełnie fikcyjne i nie związane z żadnym badanym czy badającym.
} 


\subsection{Plansza ćwiczenia}

\section{Stew Dentone}

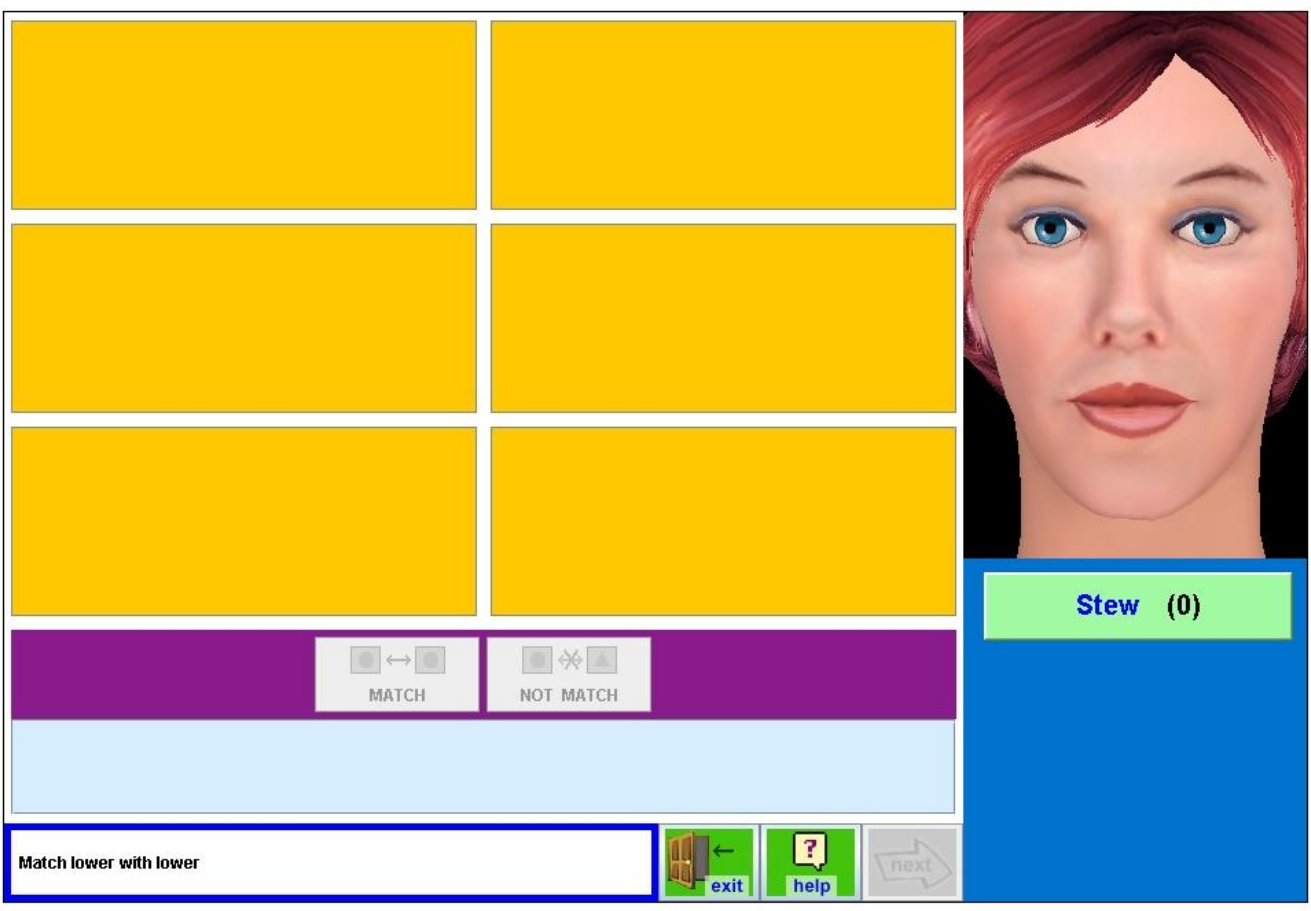

Ilustracja 1: Interfejs ćwiczenia typu Matching

Plansza ćwiczenia typu Matching to sześć prostokątów, pod którymi są „ukryte” litery. Litery ukazują się po kliknięciu na prostokąt. Zadaniem ucznia jest kliknięcie na dowolny prostokąt i „odkrycie” litery. „Odkryciu litery towarzyszy odczytanie jej przez $W N$ czyli podanie nazwy takiej jaka jest jej przypisana w angielskim alfabecie. Po odkryciu dwóch liter, przyciski MATCH i NOT MATCH aktywują się. Uczeń musi teraz zdecydować czy „odkryte” litery pasują do siebie. Odpowiedź uczeń podaje klikając na jeden przycisków: jeśli pasują - MATCH, jeśli nie NOT MATCH. W przypadku liter pasujących do siebie kliknięcie MATCH wygasza dwa prostokąty z tymi literami, a w przypadku różnych liter (odpowiedź błędna), litery są z powrotem zakrywane. Kliknięcie NOT MATCH również powoduje zakrycie liter. Dopasowane litery (trzy) ukazują się pod przyciskami MATCH. Gdy uczeń odkryje wszystkie sześć prostokątów i ustali, które litery pasują do siebie, gra kończy się. Wówczas aktywuje się przycisk NEXT i uczeń może wyjść z gry (wcześniej wyjście z gry jest możliwe przyciskiem EXIT).

\subsection{Warunki poprawnego wykonania ćwiczenia}

Zaprogramowano dwa warianty ćwiczenia typu Matching: Matching Lower-Lower i Matching Lower-Upper. Oba ćwiczenia opierają się na dyskryminacji bodźców akustycznych i wizualnych ściśle związanych z językiem i pismem (czytaniem). Pierwsze polega na dopasowaniu małych liter alfabetu do siebie. Sprowadza się ono do ustalenia czy dwa znaki obrazują tą samą literę czy są tożsame (bodziec wizualny: litery na ekranie) i czy mają taką samą nazwę (bodziec akustyczny: głos $W N$ ). Drugie polega na dopasowaniu małej litery do wielkiej (bądź odwrotnie, zależnie od trafionych liter). Dokładniej chodzi o ustalenie czy dwa graficznie (bodźce wizualne) różne znaki obrazują tę samą literę - czy są tożsame pod względem pozycji w alfabecie i czy mają taką samą nazwę (bodziec akustyczny: głos $W N$ ). 
W ćwiczeniu Matching Lower-Upper odkrywane litery są nazywane przez Marni wraz $\mathrm{z}$ określeniem wielkośći ${ }^{14}$ litery: lowercase lub uppercase. Zatem nazwa małej litery $p$ brzmi lowercase [pi:], a wielkiej - uppercase [pi:]. Polski uczeń wczesnoszkolny nie musi rozumieć tych określeń, lecz zna nazwy liter. Ponadto nazwy angielskich liter częściowo nawiązują do ich brzmienia (głosek, które dana litera symbolizuje) znanego dzieciom z języka polskiego w stopniu podstawowym ${ }^{15}$. Można zatem postawić hipotezę, że dziecko potrafi zdecydować czy widoczne na ekranie znaki mają taką samą czy różną nazwę podawaną przez Marni. To właśnie jest warunkiem poprawnego wykonania ćwiczeń typu Matching.

\subsection{Znajomość liter alfabetu polskiego oraz liter alfabetu angielskiego}

Oczywiście rozpoznawanie liter alfabetu angielskiego dla dzieci polskich na początku szkoły podstawowej nie jest trudne, bo znają już litery polskiego alfabetu. Wiedzą już, że litery stosowane w tych językach nie różnią się formą, a o tym, że w języku angielskim nie występują polskie litery $\mathrm{z}$ diakrytykami ${ }^{16}$ przekonują się $\mathrm{w}$ pierwszych miesiącach nauki. Wtedy także dowiadują się, że w alfabecie angielskim jest mniej liter ( $26 \mathrm{w}$ porównaniu 35 . w polskim) i poznają trzy litery $\mathrm{Q}, \mathrm{V}$ i X, które $\mathrm{w}$ języku polskim stosowane są bardzo rzadko ${ }^{17}$. Drobne różnice formalne i ilościowe liter alfabetów tych dwóch języków są właściwie nieistotne na początku nauki. Używanie tych samych znaków do zapisu polskich i angielskich słów stanowi zresztą spore ułatwienie w nauce (w porównaniu np. z językiem rosyjskim, w przypadku którego należy nauczyć się nowego alfabetu grażdanki). Dzięki temu uczniom nieobca jest zasada alfabetyczna - odpowiedniości litera-głoska, po drugie znane są $\mathrm{w}$ większości litery alfabetu łacińskiego ${ }^{18}$ Najważniejsze różnice kryją się w wartości i funkcji liter alfabetu łacińskiego w języku rodzimym i obcym.

\subsection{Umiejętności dziecka potrzebne do wykonania ćwiczeń $C L T$}

Pozornie proste, bo polegające na porównywaniu liter, ćwiczenie ma na celu kształcenie szeregu umiejętności poznawczych dziecka. Wykonanie ćwiczenia wymaga od ucznia koncentracji, uwagi, pamięci i zdolności metakognitywnych oraz koordynacji ruchowej. Dziecko skupia uwagę na ekranie komputera, a szczególnie na planszy gry, która zajmuje blisko połowę powierzchni ekranu. Litery stanowią bodźce wizualne, podczas gdy komunikaty głosowe Marni są bodźcami słuchowymi. Dyskryminacja tych bodźców jest prawie jednoczesna, gdyż dziecko słyszy nazwę litery zaraz po jej odkryciu (kliknięciu na jeden z sześciu prostokątów) i może ją usłyszeć dowolną liczbę razy (klikając na prostokąt). Podjęcie decyzji o pasowaniu do siebie liter (dwóch małych lub małej do wielkiej) wymaga skojarzenia formy dźwiękowej i wizualnej czyli integracji zmysłowej.

\subsubsection{Pamięć}

Potrzebę wykorzystania pamięci przedstawia następująca sytuacja. Jeśli w pierwszych kliknięciach uczeń trafił na różne litery i klikając NOT MATCH uznał je za różne to litery zostawały z powrotem zakryte. Tylko dwie litery mogą być odkryte jednocześnie. Dziecko łatwo zapamięta jakie litery znajdują się pod raz odkrytymi prostokątami, gdyż dąży do sprawnego rozwiązania zadania. Wie, że zadanie będzie rozwiązane, gdy odkryje wszystkie sześć kart (liter). Pamięć o tym, jakie litery

\footnotetext{
${ }^{14}$ Angielskie nazwy liter - lowercase i uppercase - pochodzą od określeń lower case i upper case, gdzie case oznaczało kasztę do przechowywania liter w drukarni. Druk maszynowy został zastąpiony cyfrowym, ale nazwy liter nie zmieniły się. Język polski nie pozwala na wspólne nazwanie liter dużych i małych słowem, który odpowiadałby case, choć w polskiej wersji edytora tekstu Microsoft Word 2003 polecenie Change Case przetłumaczono na Zmień wielkości liter. ${ }^{15}$ Potwierdzają to przykłady liter oraz nazw angielskich i polskich: $\mathrm{p}-[\mathrm{pi}:]-[\mathrm{pe}], \mathrm{b}-[\mathrm{bi}:]-[\mathrm{be}], \mathrm{d}-[\mathrm{di}:]-[\mathrm{de}] \mathrm{czy} \mathrm{s}-[\varepsilon \mathrm{s}]$ - [es] lub $1-[\varepsilon l]-[e l]$. Jednakże są także przykłady nazw angielskich niemotywowanych brzmieniem oznaczanej głoski angielskiej: h - [eitf] - [ha] czy w - ['d $\Lambda b(\partial) 1$ ju:] - [vu].

${ }^{16}$ Diakrytyki w języku angielskim są używane tylko w zapisie zapożyczeń, najczęściej z francuskiego np.: façade fasada i naïve - naiwny czy résumé. Ich używanie nie jest jednak obligatoryjne, a słowa tego typu są tak rzadkie, że dzieciom w polskiej szkole podstawowej na pewno nie są znane. Stąd wniosek, że fakt używania diakrytyków w języku angielskim można w niniejszym badaniu pominąć.

${ }^{17}$ Pytanie: jak rzadko litery $Q, V$ i $X$ są stosowane w języku polskim wymagałoby odrębnego omówienia. Słowniki PWN np.: Inny Stownik Języka Polskiego lub Uniwersalny Stownik Języka Polskiego podają bardzo mało haseł z tymi literami. ${ }^{18}$ Nazwa alfabet łaciński odnosi się do alfabetycznego systemu pisma stosowanego w większości języków Europy (z wyjątkiem rosyjskiego, bułgarskiego i innych), obu Ameryk i niektórych języków Azji (np. wietnamski) oraz Australii. Alfabety używane w tych językach różnią się formalnie znakami diakrytycznymi i wartością fonetyczną liter, lecz wszystkie wywodzą się z alfabetu łacińskiego.
} 
kryją się za określonymi prostokątami pomoże rozwiązać zadanie szybciej i w mniejszej liczbie kroków. Ponadto ćwiczona jest także pamięć o związku litery z jej dźwiękową nazwą.

\subsubsection{Zdolności metakognitywne}

W wykonywaniu ćwiczeń językowych nie bez znaczenia są także zdolności metakognitywne dziecka. Ćwiczenie jest grą, ekran komputera przedstawia pewien problem, a Marni oczekuje, że dziecko znajdzie jego rozwiązanie. Uczeń musi sobie uświadomić, jakie są zasady gry i znaleźć sposób na wykonanie zadania. W tym celu musi dokonywać analizy dostępnych mu danych (litery i ich nazwy) i możliwych kroków (ruchów). Wyniki badań wskazują jednoznacznie na efektywność zdolności metakognitywnych polskich dzieci wczesnoszkolnych w nieznanych im przecież ćwiczeniach w języku angielskim. Nie zdarzało się, by któreś z dzieci odmówiło wykonania ćwiczenia ze względu na zbyt wysoki poziom trudności. Sporadycznie i tylko na początku ćwiczeń niektóre $\mathrm{z}$ dzieci pytały ekspetymentatora czy dobrze klikają, czy mogą nacisnąć wskazywany kursorem przycisk. Zawsze odpowiadano: spróbuj; zobacz, co się stanie; przekonaj się. Skłanianie ucznia do samodzielnej interakcji z komputerem ma na celu wspieranie autonomii w nauce.

\subsection{Rola Wirtualnej Nauczycielki w ćwiczeniach $C L T$}

W ćwiczeniach CLT (Tutors) uczeń ma szansę przekonać się o własnych możliwościach intelektualnych podczas nauki, a proces nauczania jest regulowany przez Wirtualna Nauczycielke (Wise [w druku]). Wskazówki dawane przez Marni są minimalne, gdyż mają tylko naprowadzać ucznia na możliwe rozwiązania. W ten sposób realizowana jest idea strefy najbliższego rozwoju Wygotskiego (Wolf, Vellutino, and Gleason 2005) definiowana u Schaffera jako „rozstęp pomiędzy tym, co dziecko jest w stanie osiągnąć bez pomocy, a tym, co może osiągnąc przy pomocy osoby posiadającej większą wiedzę" (Schaffer 2005). Instruktaż we wszystkich ćwiczeniach $C L T$ jest prowadzony tak, by Marni naśladowała dorosłego (nauczyciela lub rodzica) dziecka, o którym Schaffer pisze:

„Dorosły powinien być wrażliwy zarówno na osiągnięcia dziecka, jak i na jego potencjał i z odpowiednim wyczuciem formułować wyzwania intelektualne tak, by nie wykraczały dalej niż jeden krok ponad to, co dziecko potrafi już zrozumieć. Poprzez wykorzystanie już posiadanej przez dziecko wiedzy można w ten sposób prowadzić je ku dalszym osiągnięciom.” (Schaffer 2005).

Marni pomaga dziecku w ustaleniu związków (skojarzeń) pomiędzy znakami dźwiękowymi (głoskami i nazwami liter) a ich graficznymi (literami). Na każde kliknięcie na kartę lub literę Marni reaguje podając brzmienie głoski oznaczanej przez literę i nazwę tej litery. Wirtualna Nauczycielka powtórzy nazwę głoski czy wyraz (w innym ćwiczeniu) tyle razy, ile uczeń tego potrzebuje i nie okazuje przy tym zniecierpliwienia, zdziwienia czy zmęczenia. Zależnie od działań dziecka, Marni wyjaśni czy dziecko postępuje zgodnie z jej oczekiwaniami i pochwali za poprawną odpowiedź. Awatar odgrywa więc rolę niestrudzonego eksperta gotowego pomóc dziecku w każdej (przewidzianej przez program) sytuacji.

Zalety włączenia idei strefy najbliższego rozwoju Wygotskiego w edukację wspomaganą komputerowo podkreślano już ćwierć wieku temu, a więc jeszcze zanim komputery stały się tanie, dostępne i popularne (dosłownie: osobiste). W artykule o integracji inteligencji ludzkiej i komputerowej wydanym w zbiorze artykułów Children and Computers w 1985 roku napisano:

"It is posible that future versions of $\mathrm{AI}^{19}$ systems could serve as tools for helping children move trough the zones of proximal development by extending the "social" environment for cognitive growth by interactively providing hints and support in problem-solving tasks like the one adults provide. Computers playing this role will be information age sequel to concepts of a zone of proximal zone development, in which the adult human plays the tutorial role of coconstructing with the child his of her latent developmental capabilities. In this case, the zone of proximal development is traversed with the complementary capabilities of the human-computer system." (Pea 1985)

Przytoczony fragment zapowiada systemy sztucznej inteligencji zdolne do tutorowania czyli nauczania lub wspomagania nauczania dla dzieci. Program $C L T$ jest potwierdzeniem tezy Pea

\footnotetext{
${ }^{19}$ Artificial Intelligence czyli Sztuczna Inteligencja
} 
i jednym z lepszych przykładów takich systemów. Głównym zadaniem Wirtualnej Nauczycielki $\mathrm{w}$ tej perspektywie jest modelowanie rozwoju poznawczego (językowego) dziecka i projekcja strefy najbliższego rozwoju. Marni, tak jak dorosły czy nauczyciel „ko-konstruuje” z dzieckiem jego zdolności poznawcze, stwarzając rodzaj kontrolowanego, bezpiecznego, środowiska rozwojowego, w którym dziecko może się poczuć niczym w „kokonie” (sic!). Zniechęconych do nauki czytania Marni zachęci do zabawy, a nieoswojonych z komputerem - zaprosi do interakcji.

Dzieci uczące się w programie CLT poznają także fundamentalne zasady komunikacji międzyludzkiej, gdyż wypowiedzi Marni są na niej wzorowane. Osłuchują się z naturalną i oryginalną intonacją języka angielskiego i zaczynają rozumieć jej znaczenia, związki z sytuacją zaistniałą w grze. Systemy sztucznej inteligencji zyskują coraz większą rolę w enkulturacji i stają się przekazicielami wiedzy kulturowej, w tym wiedzy o języku czy kompetencji komunikacyjnej w rozumieniu Hymesa. Zakładając, że komputery i programy tak zaawansowane technicznie i absorbujące jak $C L T$ będą często wykorzystywane w nauce i wspomaganiu rozwoju dziecka, można postawić hipotezę, że te najnowsze narzędzia symboliczne będą częścią systemu wsparcia przyswajania języka ${ }^{20}$.

\subsection{Prezentacja danych zebranych przez $M L E$}

W poprzednim artykule na temat CLT (Juszczyk 2005) przedstawiono szczegółowy transkrypt z przebiegu ćwiczenia typu Matching na podstawie obserwacji jednego z badanych uczniów. Zapis oparto na obserwacjach i nagraniach programu rejestrującego dźwięk i obraz z ekranu komputera. Dostępna wówczas wersja $C L T$ nie współpracowała z MLE, więc wyniki nie były rejestrowane przez program zarządzający nauczaniem. Wyniki ćwiczeń nie były zatem dostępne przez serwis stron www. Obecna wersja $C L T$, dzięki stałemu połączeniu z MLE (przez Internet), daje możliwość zapisania (automatycznego) przebiegu ćwiczeń wykonywanych przez każde dziecko z osobna i zebrania wyników wszystkich badanych dzieci w celu porównania i podsumowania.

\subsubsection{Tabela indywidualna}

System MLE gromadzi rezultaty działań uczniów i zlicza dane istotne dla procesu nauczania. Odpowiednie skrypty na stronie WWW generują przystępne raporty (Report: All Activity for Current User) prezentujące poczynania każdego z uczniów osobno w tabeli. Raport można ograniczyć do wybranych ćwiczeń przez wybór z menu Tutor. Przykładem raportu tego typu jest tabela 1 ukazująca wyniki ćwiczeń typu Matching u jednego z uczniów - chłopca z pierwszej klasy. Kolejne kolumny podają nazwy: etapów nauczania (State), ćwiczeń (Tutor) trybów ćwiczeń (Type) i poziomów (Level) oraz dane liczbowe: liczba odpowiedzi poprawnych (Correct) i liczba przykładów lub kroków w danym ćwiczeniu (Total). Ostatnia kolumna podaje czas spędzony na wykonaniu ćwiczenia.

Ćwiczenia powtarzają się zależnie od postępów ucznia i ich oceny przez CLT/MLE. Wedle założeń twórców $C L T$, dzieci mają ćwiczyć nowe umiejętności aż osiągną biegłość w zakresie określonym przez ćwiczenia i plan nauczania. Biegłość (competence) wyznaczana jest stosownie do procentu dokładności i/lub liczby klików myszki, za pomocą których uczeń odsłuchuje przykłady (w danym ćwiczeniu) zanim wybierze odpowiedź. Program ma podwyższać poziom trudności (Level) ćwiczeń, gdy uczeń uzyska 80\% lub więcej biegłości przy dwóch kolejnych przykładach podanych w ćwiczeniu. Jeśli uzyska poniżej $50 \% \mathrm{w}$ dwóch seriach przykładów lub $20 \% \mathrm{w}$ jednej serii, program obniży poziom trudności bez uprzedzania ucznia. Dzięki temu Marni zachowuje się jak „doświadczony nauczyciel ludzki” (expert human tutor), który dostosowuje materiał ćwiczeniowy do aktualnych możliwości konkretnego dziecka (Wise [w druku]).

Ponadto większość ćwiczeń $C L T$ (nie dotyczy to ćwiczeń typu Matching, gdzie podaje się tylko 3 pary przykładów) zaczyna się od jednego lub dwóch przykładów z ćwiczenia, które dziecku poszło dobrze. To zapewnia uczącemu się strefe najbliższego rozwoju, po której zadawana jest seria 7-8 przykładów wraz wyjaśnieniem. Ćwiczenia kończą się powtórką dobrze znanych przykładów czyli znów strefa najbliższego rozwoju (Wise [w druku]).

\footnotetext{
${ }^{20}$ Chodzi oczywiście o Language Aquisition Support System Jerome Brunera (Schaffer 2005).
} 
Tabela 1: Indywidualny raport ćwiczeń dla ucznia KAPPA1M ${ }^{21}$

\begin{tabular}{|c|c|c|c|c|c|c|c|}
\hline \multicolumn{8}{|c|}{ TUTOR SUMMARY FOR KAPPA1M } \\
\hline NR & STATE & TUTOR & TYPE & LEVEL & CORRECT & TOTAL & $\begin{array}{l}\text { DURATION } \\
\text { (MIN) }\end{array}$ \\
\hline 1 & 0.10: Alphabet 1: Learn consonant letters & Lowercase 4-Square & Practice & $\begin{array}{l}\text { [1] Alphabet } \mathrm{f}, \mathrm{v}, \\
\mathrm{p} \text { and b }\end{array}$ & 10 & 10 & 0.55 \\
\hline 2 & 0.10: Alphabet 1: Learn consonant letters & Lowercase 4-Square & Practice & $\begin{array}{c}\text { [1] Alphabet f, v, } \\
\text { p and b }\end{array}$ & 5 & 11 & 6.18 \\
\hline 3 & 0.10: Alphabet 1: Learn consonant letters & $\begin{array}{l}\text { Matching Lower - } \\
\text { Lower }\end{array}$ & Practice/Test & $\mathrm{N} / \mathrm{A}$ & 5 & 7 & 2.27 \\
\hline 4 & $\begin{array}{l}0.20 \text { : Alphabet } 2 \text { : Learn i, a and consonant } \\
\text { letters and 0.21: Letter-sound } 1: \text { Match } \\
\text { initial consonants }\end{array}$ & Lowercase 4-Square & Practice & [4] Alphabet i, a, j & 14 & 28 & 10.02 \\
\hline 5 & $\begin{array}{l}0.20 \text { : Alphabet } 2 \text { : Learn i, a and consonant } \\
\text { letters and } 0.21 \text { : Letter-sound } 1: \text { Match } \\
\text { initial consonants }\end{array}$ & Lowercase 4-Square & Practice & $\begin{array}{l}\text { [3] Alphabet s, z, } \\
\text { m and n }\end{array}$ & 17 & 20 & 3.21 \\
\hline
\end{tabular}

\footnotetext{
${ }^{21}$ Pseudonimy zostały przypisane uczniom po wykonaniu badania. Nagłówek oryginalnej tabeli podaje login ucznia.
} 


\begin{tabular}{|c|c|c|c|c|c|c|c|}
\hline 6 & $\begin{array}{l}0.20 \text { : Alphabet } 2 \text { : Learn i, a and consonant } \\
\text { letters and } 0.21 \text { : Letter-sound } 1 \text { : Match } \\
\text { initial consonants }\end{array}$ & $\begin{array}{l}\text { Matching Lower - } \\
\text { Lower }\end{array}$ & Practice/Test & N/A & 4 & 4 & 1.52 \\
\hline 7 & $\begin{array}{l}\text { 0.30: Alphabet } 3 \text { : Learn e, o, u and } \\
\text { consonant letters and } 0.31 \text { : Letter-sound } \\
\text { 2: Match initial i, a and consonants }\end{array}$ & $\begin{array}{l}\text { Letters-Sounds 4- } \\
\text { Square }\end{array}$ & Practice & $\begin{array}{l}\text { [3] Consonants in } \\
\text { initial position: } \\
\text { s,z,m,n and } \\
\text { Vowels in initial } \\
\text { position: /a/ as in } \\
\text { apple and /i/ as in } \\
\text { igloo (query the } \\
\text { word that have } \\
\text { picture) }\end{array}$ & 6 & 10 & 6.22 \\
\hline 8 & $\begin{array}{l}\text { 0.30: Alphabet } 3 \text { : Learn e, o, u and } \\
\text { consonant letters and } 0.31 \text { : Letter-sound } \\
\text { 2: Match initial i, a and consonants }\end{array}$ & $\begin{array}{l}\text { Uppercase and } \\
\text { Lowercase 4-Square }\end{array}$ & Practice & $\begin{array}{l}\text { [5] Alphabet l, r, } \\
\text { o, e and u }\end{array}$ & 10 & 11 & 4.22 \\
\hline 9 & $\begin{array}{l}\text { 0.30: Alphabet } 3 \text { : Learn e, o, u and } \\
\text { consonant letters and } 0.31: \text { Letter-sound } \\
\text { 2: Match initial i, a and consonants }\end{array}$ & Lowercase 4-Square & Practice & $\begin{array}{l}\text { [5] Alphabet } 1, \mathrm{r} \\
\text { o, e and u }\end{array}$ & 2 & 6 & 4.34 \\
\hline 10 & $\begin{array}{l}\text { 0.30: Alphabet } 3 \text { : Learn e, o, u and } \\
\text { consonant letters and } 0.31 \text { : Letter-sound } \\
\text { 2: Match initial i, a and consonants }\end{array}$ & Lowercase 4-Square & Practice & $\begin{array}{l}\text { [5] Alphabet } 1, \mathrm{r} \\
\text { o, e and u }\end{array}$ & 1 & 2 & 1.34 \\
\hline 11 & $\begin{array}{l}\text { 0.30: Alphabet } 3 \text { : Learn e, o, u and } \\
\text { consonant letters and } 0.31 \text { : Letter-sound } \\
\text { 2: Match initial i, a and consonants }\end{array}$ & $\begin{array}{l}\text { Matching Lower - } \\
\text { Upper }\end{array}$ & Practice/Test & N/A & 1 & 4 & 2.15 \\
\hline 12 & $\begin{array}{l}\text { 0.40: Letter-sound 3: Match initial e, o, u } \\
\text { and consonants and 0.41: Beginning } \\
\text { Sound 1: Find consonants in i, a words }\end{array}$ & Beginning Sounds & Practice & $\begin{array}{l}\text { [1] CVC /a/ /i/, } \\
\text { initial position: } \mathrm{p} \\
\text { b, f, v. }\end{array}$ & 3 & 4 & 3.34 \\
\hline
\end{tabular}




\begin{tabular}{|c|c|c|c|c|c|c|c|}
\hline 13 & $\begin{array}{l}\text { 0.40: Letter-sound 3: Match initial e, o, u } \\
\text { and consonants and 0.41: Beginning } \\
\text { Sound 1: Find consonants in i, a words }\end{array}$ & $\begin{array}{l}\text { Letters-Sounds 4- } \\
\text { Square }\end{array}$ & Practice & $\begin{array}{l}\text { [4] Consonants in } \\
\text { initial position: sh } \\
\text { ch } \mathrm{j} \text { and Vowels } \\
\text { in initial position: } \\
\text { /e/ as in egg } \\
\text { (query the word } \\
\text { that have picture) }\end{array}$ & 21 & 27 & 10.52 \\
\hline 14 & $\begin{array}{l}0.50 \text { : Beginning Sound 2: Find digraphs } \\
\text { and consonants in short vowel words }\end{array}$ & Beginning Sounds & Practice & $\begin{array}{l}\text { [4] CVC /a/ /i/ /e/, } \\
\text { initial position: sh } \\
\text { ch , j. }\end{array}$ & 6 & 7 & 4.05 \\
\hline 15 & $\begin{array}{l}0.50 \text { : Beginning Sound 2: Find digraphs } \\
\text { and consonants in short vowel words }\end{array}$ & Beginning Sounds & Practice & $\begin{array}{l}\text { [4] CVC /a/ /i/ /e/, } \\
\text { initial position: sh } \\
\text { ch , j. }\end{array}$ & 9 & 10 & 2.57 \\
\hline 16 & $\begin{array}{l}0.50 \text { : Beginning Sound 2: Find digraphs } \\
\text { and consonants in short vowel words }\end{array}$ & Beginning Sounds & Practice & $\begin{array}{l}\text { [4] CVC /a/ /i/ /e/, } \\
\text { initial position: sh } \\
\text { ch , j. }\end{array}$ & 11 & 11 & 3.13 \\
\hline 17 & $\begin{array}{l}\text { 0.50: Beginning Sound 2: Find digraphs } \\
\text { and consonants in short vowel words }\end{array}$ & Beginning Sounds & Practice & $\begin{array}{l}\text { [4] CVC /a/ /i/ /e/, } \\
\text { initial position: sh } \\
\text { ch , j. }\end{array}$ & 5 & 7 & 5.28 \\
\hline \multicolumn{5}{|c|}{ Total } & 132 & 179 & 01:14.11 \\
\hline
\end{tabular}




\subsubsection{Tabela zbiorcza dla ćwiczeń typu Matching}

Przeprowadzone badania pozwalają na porównanie wyników w grupie dzieci. W tym celu zebrano tabele indywidualne osiągnięć kolejnych uczniów i sporządzono zestawienie wyników wszystkich ćwiczeń przerobionych przez 14 dzieci w klasie 1 i $10 \mathrm{w}$ drugiej. Fragment zestawienia przedstawia tabele osiągnięć dzieci z 1 klasy. Dzieciom nadano pseudonimy składające się z nazw liter greckich, oznaczenia klasy i płci (K - dziewczynka, $\mathrm{M}$ - chłopiec). Tabela 2 ukazuje wyniki dla ćwiczenia Matching Lower - Lower, a tabela 3 -Matching Lower - Upper. ${ }^{22}$

Liczba wykonanych ćwiczeń przez dane dziecko jest zależna od oceny dokonanej przez CLT i $M L E$, badający nie miał wpływu na dobór ćwiczeń. Jeśli dokładnie przyjrzymy się wynikom zebranym w tabelach, okaże się, że są niekompletne. Niestety na skutek błędnego działania CLT i MLE nie wszystkie dane dotyczące przebiegu wykonywanych ćwiczeń zostały przesłane na serwer www i dlatego tabela nie obejmuje wszystkich danych przebadanych dzieci dla wybranych ćwiczeń. Należy także dodać, iż, w trakcie badań doszło do nielicznych awarii testowanego programu $C L T$.

Nagłówki kolumn nawiązują do nagłówków tabeli 1, a więc Correct przełożono jako POPRAWNE, a Total jako WSZYSTKIE. Liczby w kolumnie POPRAWNE mówią nam ile razy uczeń kliknął prawidłowo czyli na przycisk $M A T C H$, gdy odkryte litery zgadzały się lub na NOT MATCH, gdy litery nie zgadzały się. Natomiast w kolumnie WSZYSTKIE podano liczby wszystkich kliknięć przycisków MATCH i NOT MATCH - poprawnych i niepoprawnych. Pozycje tabeli są posortowane wg dwóch kryteriów: procentu poprawnych odpowiedzi (kolumna: \%) i czasu wykonania zadania w minutach.

Tabela 2: Porównanie wyników ćwiczenia Matching Lower-Lower

\begin{tabular}{|cccccr|}
\hline $\mathrm{nr}$ & UCZEN & POPRA WNE & WSZYSTKIE & $\%$ & CZAS \\
1. & ALFA1K & 5 & 5 & 100 & 1,08 \\
\hline 2. & BETA1K & 5 & 5 & 100 & 1,19 \\
\hline 3. & JOTA1M & 5 & 5 & 100 & 1,21 \\
\hline 4. & TAU1K & 4 & 4 & 100 & 1,24 \\
\hline 5. & LAMBDA1K & 5 & 5 & 100 & 1,27 \\
\hline 6. & EPSILON1M & 4 & 4 & 100 & 1,31 \\
\hline 7. & TAU1K & 5 & 5 & 100 & 1,32 \\
\hline 8. & KAPPA1M & 4 & 4 & 100 & 1,52 \\
\hline 9. & PSI1M & 10 & 10 & 100 & 2,16 \\
\hline 10. & OMEGA1K & 4 & 4 & 100 & 2,20 \\
\hline 11. & DELTA1M & 5 & 5 & 100 & 2,31 \\
\hline 12. & TAU1K & 6 & 7 & 86 & 3,06 \\
\hline 13. & OMEGA1K & 5 & 6 & 83 & 1,17 \\
\hline 14. & GAMMA1K & 3 & 4 & 75 & 1,10 \\
\hline 15. & KAPPA1M & 5 & 7 & 71 & 2,27 \\
\hline
\end{tabular}

\footnotetext{
${ }^{22}$ Tabela ta powstała przez scalenie raportów MLE.
} 
Tabela 3: Porównanie wyników ćwiczenia Matching Lower- Upper

\begin{tabular}{|cccccc|}
\hline $\mathrm{nr}$ & UCZEN & POPRA WNE & WSZYSTKIE & $\%$ & CZAS \\
\hline 1. & OMIKRON1K & 4 & 4 & 100 & 0,51 \\
\hline 2. & DELTA1M & 4 & 4 & 100 & 0,54 \\
\hline 3. & SIGMA1M & 6 & 6 & 100 & 0,55 \\
\hline 4. & SIGMA1M & 5 & 5 & 100 & 1,03 \\
\hline 5. & OMIKRON1K & 6 & 6 & 100 & 1,04 \\
\hline 6. & LAMBDA1K & 7 & 7 & 100 & 1,38 \\
\hline 7. & BETA1K & 5 & 5 & 100 & 1,48 \\
\hline 8. & PSI1M & 3 & 3 & 100 & 2,13 \\
\hline 9. & TAU1K & 4 & 4 & 100 & 2,15 \\
\hline 10. & ALFA1K & 9 & 9 & 100 & 3,03 \\
\hline 11. & THETA1M & 6 & 7 & 86 & 1,16 \\
\hline 12. & KAPPA1M & 2 & 4 & 50 & 2,27 \\
\hline
\end{tabular}

Wyniki zebrane w tabelach pozwalają sądzić, że oba ćwiczenia okazały się proste, większość dzieci rozwiązała zadanie w zupełności poprawnie (100\% uzyskano odpowiednio w 11 na 15 ćwiczeń Matching Lower - Lower i w 10 na 12 ćwiczeń Matching Lower - Upper). Różne były jednak strategie i przebiegi wykonywanych ćwiczeń, co widać po liczbie wszystkich kliknięć (WSZYSTKIE). Im większa, tym więcej razy uczeń odsłuchiwał i porównywał głoski i litery. Należy jednak pamiętać, że ćwiczenia te nie są testem, lecz okazją do nauczenia się angielskich nazw liter i skojarzeń formy graficznej $\mathrm{z}$ dźwiękową. Proces uczenia się pokazuje raport szczegółowy, w który podaje kolejne kroki (kliknięcia), jakie wykonał uczeń zanim rozwiązał zadanie. Przykładem takiego raportu jest opisywana niżej tabela szczegółowa.

\subsubsection{Tabela szczególowa dla ćwiczenia Matching Lower - Lower}

System kontroli ćwiczeń MLE rejestruje także dokładny przebieg wszystkich ćwiczeń. W przypadku ćwiczeń typu Matching otrzymujemy szczegółową tabelę z podglądem liter trafionych przez ucznia (First Item i Second Item) i czasu jaki minął pomiędzy kliknięciami i klikane przyciski MATCH lub NOT MATCH oraz oceny odpowiedzi (kolumna Answer). Wspomniany czas mijający pomiędzy kliknięciami odzwierciedla czas analizy i podjęcia decyzji przez ucznia, a więc również zdolność do identyfikacji liter i ich nazw. Widoczne w tabeli 4. czasy sugerują, że litery były odkrywane szybko, a podjęcie decyzji: MATCH/NOT MATCH zajmowało od 3 do 44 sekund. Krótkie czasy są dużo częstsze, co świadczy o biegłości ucznia, a dłuższe czasy (12, 24 i 44 sekundy) oznaczają momenty wahania i zastanawiania się. Najdłuższy czas (44 sekundy) mógł być częściowo spowodowany rozproszeniem uwagi i niepewnością ucznia co zrobić - gdzie kliknąć. Tabela 4 odtwarza także układ liter na planszy (kolumna Board).

Prezentowana tabela szczegółowa ukazuje także pewną strategię ucznia. Najprawdopodobniej odkrywał kolejne litery klikając losowo w karty, dzięki czemu dowiedział się, które karty zakrywają określone litery. Potem powtarzał klikanie tak, by trafić na pasujące do siebie litery. Stosowanie takiej strategii wymaga skupienia uwagi na skutkach klikania, zaangażowania pamięci roboczej (operacyjnej) i analizy bodźców wizualnych (litery) oraz dźwiękowych (nazwy liter). Fakt, że ćwiczenie zostało w większości poprawnie wykonane potwierdza pogląd, że dzieci wczesnoszkolne wykazują się już sporą elastycznością stosowanych strategii poznawczych (Schaffer 2005). 
Tabela 4: Szczegółowy raport przebiegu ćwiczenia Matching Lower - Lower ${ }^{23}$

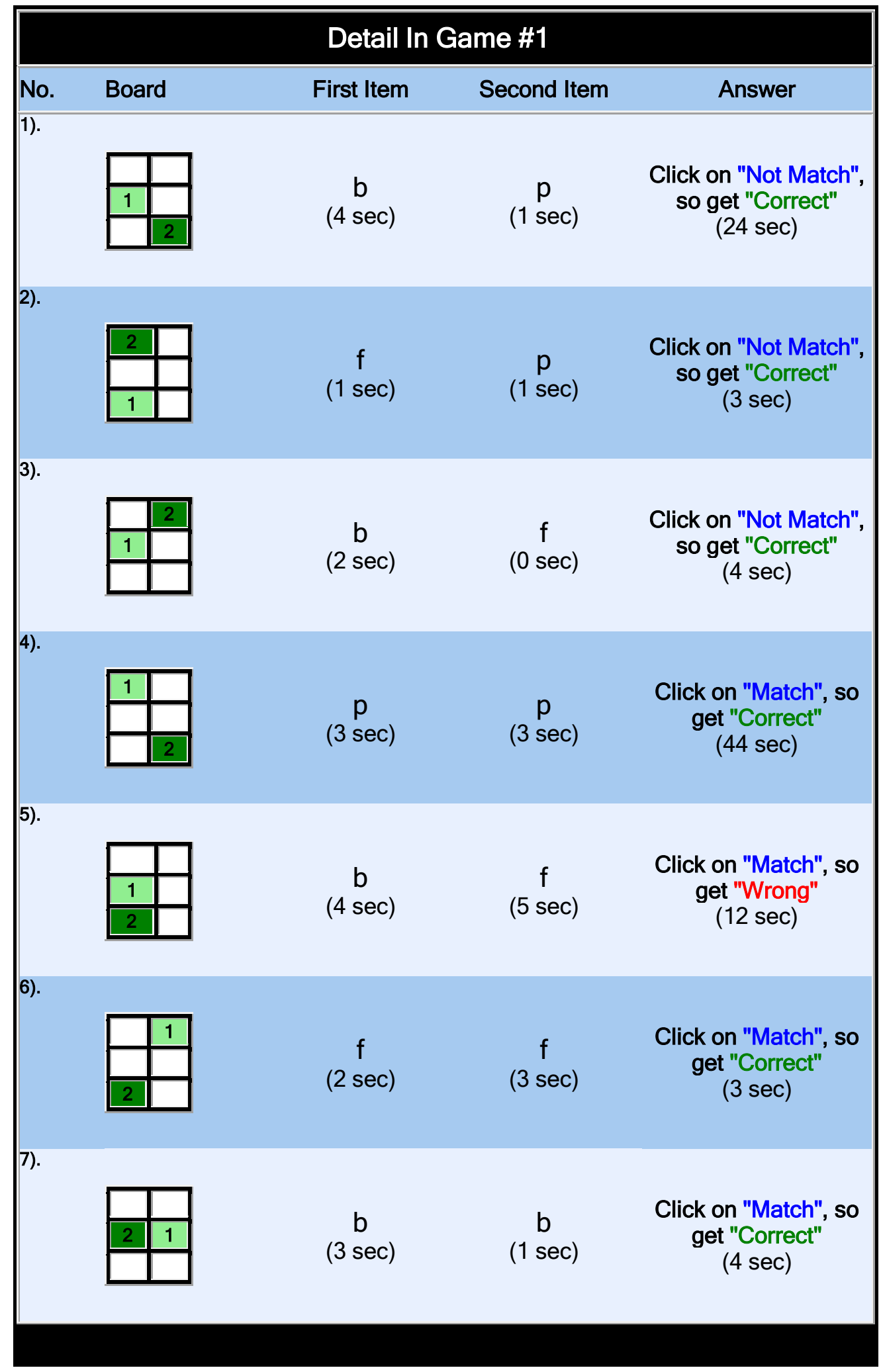

\footnotetext{
${ }^{23}$ Zachowano oryginalne kolory $M L E$.
} 
Wybrana tabela szczegółowa pochodzi z ćwiczenia wykonanego przez dziewczynkę (TAU1K). Widzimy siedem kroków, których typy zostaną poddane analizie. Inne tabele szczegółowe ćwiczeń typu Matching są podobne, różnią się głównie trafianymi literami, ich pozycją, czasem pomiędzy kliknięciami i liczbą kroków czyli wszystkich kliknięć przycisków MATCH lub NOT MATCH (kolumna WSZYSTKIE w tabeli 2. i 3.).

Rodzaje kroków powtarzają się w pozostałych tabelach, różna jest tylko ich liczba i kolejność. MLE wyróżnia następujące rodzaje kroków (kliknięć przycisków MATCH lub NOT MATCH):

$>$ kliknięcie MATCH przy pasujących do siebie literach (Click on "Match", so get "Correct")

> kliknięcie NOT MATCH przy niepasujących do siebie literach (Click on "Not Match", so get "Correct")

> kliknięcie MATCH przy niepasujących do siebie literach (Click on "Match", so get "Wrong")

> kliknięcie NOT MATCH przy pasujących do siebie literach (Click on "Not Match", so get "Wrong")

Podane $\mathrm{w}$ nawiasach opisy nawiązują do oryginalnych określeń $M L E \mathrm{w}$ tabeli szczegółowej (tabela 4). Ponieważ w przeprowadzonych badaniach odpowiedzi błędnych było bardzo mało, dwa ostatnie typy kroków zdarzały się bardzo rzadko (5 na 80 i 7 na 70 odpowiednio w ćwiczeniach Matching Lower - Lower i Matching Lower - Upper). Najrzadszy jest ostatni z króków: kliknięcie NOT MATCH przy pasujących do siebie literach. Jednokrotne wystąpienie w ćwiczeniu Matching Lower - Lower można uznać za błąd spowodowany brakiem uwagi dziecka, a czterokrotne wystąpienie w ćwiczeniu Matching Lower - Upper może oznaczać, że niektóre z badanych dzieci nie orientują się jeszcze w odpowiedniości liter małych i dużych. Drugie ćwiczenie typu Matching jest zatem trochę trudniejsze. Tabele 5 i 6 podają liczby wystąpień 4 rodzajów kroków w ćwiczeniach typu Matching wyliczone na podstawie analizy wszystkich tabel szczegółowych:

Tabela 5. Liczba wystapień 4 rodzajów kroków w ćwiczeniu Matching Lower - Lower

\begin{tabular}{|cccc|}
\hline $\begin{array}{c}\text { LITERY TOŻSAME } \\
\text { Click on "Match", so } \\
\text { get "Correct" }\end{array}$ & $\begin{array}{c}\text { LITERY RÓŻNE } \\
\text { so get "Correct" }\end{array}$ & $\begin{array}{c}\text { LITERY TOŻSAME } \\
\text { slick on "Not Match", } \\
\text { so get "Wrong" }\end{array}$ & $\begin{array}{c}\text { LITERY RÓŻNE } \\
\text { Click on "Match", so } \\
\text { get "Wrong" }\end{array}$ \\
\hline 50 & 25 & 1 & 4 \\
\hline
\end{tabular}

Tabela 6. Liczba wystapień 4 rodzajów kroków w ćwiczeniu Matching Lower - Upper

\begin{tabular}{|cccc|}
\hline $\begin{array}{c}\text { LITERY TOŻSAME } \\
\text { Click on "Match", so } \\
\text { get "Correct" }\end{array}$ & $\begin{array}{c}\text { LITERY RÓŻNE } \\
\text { so get "Correct" }\end{array}$ & $\begin{array}{c}\text { LITERY TOŻSAME } \\
\text { click on "Not Match", } \\
\text { so get "Wrong" }\end{array}$ & $\begin{array}{c}\text { LITERY RÓŻंick on "Match", so } \\
\text { get "Wrong" }\end{array}$ \\
\hline 35 & 28 & 2 & 5 \\
\hline
\end{tabular}

Przedstawione w powyższych tabelach kroki są skutkiem działań dziecka. Uczeń rozwiązujący zadanie $\mathrm{w}$ interakcji z komputerem komunikuje się z nim tylko za pomocą myszki (CLT w wersji dostępnej autorowi nie rejestruje innych zachowań użytkownika). Dlatego ważne jest zliczanie kliknięć przez system kontroli MLE. Zależnie od trafionych liter i danych odpowiedzi, dziecko słyszy różne reakcje Marni. W ten sposób toczy się dialog dziecko-komputer czyli uczeń (wirtualna) nauczycielka. Kroki (kliknięcia) można zatem uznać za ruchy dialogowe dziecka, a reakcje słowne Marni za jej ruchy dialogowe. To, że inne działania dziecka, a zwłaszcza te werbalne, nie są rejestrowane przez $C L T$, a co za tym idzie - nie są rozumiane przez Wirtualna Nauczycielkę nie oznacza, że Marni ma przewagę w tym dialogu. To dziecko steruje grą i rozwiązuje zadanie, a Marni posłusznie podaje nazwy liter, chwali za dobre odpowiedzi, a jeśli zajdzie potrzeba, tłumaczy jaka jest prawidłowa odpowiedź. Aby wypowiedzi dzieci były rozumiane przez komputer, potrzebny jest system rozpoznawania mowy, który pakiet CLT ma już zaimplementowany, lecz w ćwiczeniach Tutors nie jest on jeszcze wykorzystany (Wise [w druku]). 


\subsection{Rodzaje ruchów dialogowych Marni}

Repertuar komunikatów Marni w ćwiczeniach CLT jest różnorodny i zmienny. Dzięki temu interakcja z komputerem jest zajmująca, a dziecko nie nudzi się. Obserwacja poczynań dzieci korzystających z CLT pozwala na wyróżnienie paru kategorii ruchów dialogowych i możliwych przebiegów interakcji dziecko-komputer. Przyjęte w opisie kategorie to: POWITANIE, POLECENIE, PODANIE NAZWY LITERY, WYJAŚNIENIE i POCHWAŁA.

\subsubsection{POWITANIE}

Grę otwiera POWITANIE, które najczęściej brzmi tak:

$>$ Welcome to the Matching Game!

Pozostałe warianty wymawiane przez Marni to:

$>$ I like playing this game!

$>$ Here we go!

Takie powitania stanowią zaproszenie i zachęcenie dziecka do gry. Intonacja wskazuje na entuzjazm Wirtualnej Nauczycielki, która oczekuje zaangażowania ucznia w ćwiczeniu. Wypowiedzenie Here we go! zagrzewa do gry.

\subsubsection{POLECENIE}

Zaraz po POWITANIU pada POLECENIE - w ćwiczeniu Matching Lower - Lower jest to:

$>$ Find the lowercase letters that match!

a w ćwiczeniu Matching Lower - Upper polecenie brzmi:

$>$ Match the lower and uppercase letters!

Wypowiedzenie to, nie ma charakteru rozkazu czy nakazu. Jest to po prostu podanie polecenia, które wyznacza główny cel danego zadania.

\subsubsection{PODANIE NAZWY LITERY}

Dziecko wywołuje Marni do odczytania (nazwania) litery przez kliknięcie w kartę (czyli odkrycie litery) lub kliknięcie w literę już odkrytą. Nazwa litery obejmuje także jej wielkość (lowercase lub uppercase). Podaniu nazwy litery towarzyszą widoczne ruchy ust Marni. Animacja ta, jest obecna przy każdej wypowiedzi Marni, ale przy poznawaniu angielskich nazw liter jest szczególnie pomocna.

\subsubsection{WYJAŚNIENIE}

Ze względu na specyfikę ćwiczeń typu Matching wśród WYJAŚNIEŃ należy wyróżnić dwa podrodzaje. WYJAŚNIENIA podzielono na POZYTYWNE i NEGATYWNE, zależnie od kontekstu gry $\mathrm{w}$ jakim są podawane. Zależnie od wybranych liter i decyzji dziecka (MATCH/NOT MATCH) Marni podaje:

WYJAŚNIENIA POZYTYWNE:

$>$ Tryagain, they are a match.

$>$ Give it another try, they are a match.

$>$ Those two are a match, try again

WYJAŚNIENIA NEGATYWNE:

$>$ Those two don't go together, try again.

$>$ Try again, they are not a match.

$>$ Give it another try, they are not a match.

Przyjęte rozróżnienie jest konieczne, ale nazwy są być może niefortunne. De facto oba rodzaje WYJAŚNIEŃ mają pozytywny wydźwięk, gdyż mają zachęcać dziecko do kolejnej próby wyboru.

\subsubsection{POCHWALA}

Wypowiedzi typu pochwalnych jest najwięcej. Poniższa lista obejmuje dziesięć wypowiedzi, ich dobór podczas wykonywania ćwiczeń zdaje się być losowy:
$>$ Fantastic!
$>$ Torrific!
$>$ All right!
$>$ Well done! 


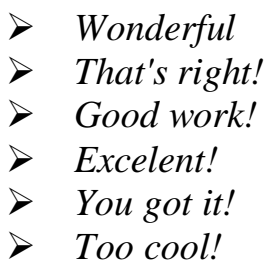

\subsubsection{Brak reakcji Marni}

Zaobserwowano także brak reakcji Marni, na niektóre działania dziecka. Trudno rozstrzygnąć czy każde kliknięcie dziecka (inne zachowania dziecka nie są jeszcze przez program rejestrowane) powinno być komentowane, czy też program czasem działa błędnie. Brak reakcji Wirtualnej Nauczycielki należy jednak uznać za reakcję zerową. Milczenie oznacza, że dziecko radzi sobie bez pomocy Marni i żadne komentarze nie są potrzebne.

\subsection{Przebieg ćwiczeń typu Matching}

Mając wyróżnione ruchy dialogowe dziecka i Marni możemy spróbować odtworzyć możliwy przebieg ćwiczenia typu Matching. Każde z ćwiczeń rozpoczyna się od POWITANIA i POLECENIA, wypowiedzi padają bezpośrednio jedna po drugiej i jednokrotnie. Od tego momentu Marni czeka na działanie ucznia i czasem mruga do niego oczami. Jak wynika z przytoczonych przykładów, Marni nie tłumaczy dziecku jak miałoby znaleźć i skojarzyć litery. Co więcej, na początkowej planszy litery są zakryte, zatem dziecko musi je odkryć samodzielnie. Marni odzywa się dopiero, gdy uczeń kliknie na którąś z kart i odkryje literę. Każde kliknięcie w literę wywołuje Marni do jej odczytania (nazwania). Uczeń może odkryć tylko dwie litery na raz, następnie musi zdecydować czy pasują do siebie czy nie. Zależnie od trafionych liter, różnych lub tożsamych i danej odpowiedzi MATCH lub NOT MATCH (4 ruchy dialogowe dziecka) Marni zareaguje w określony przez autorów programu sposób:

$>$ kliknięcie MATCH przy tożsamych literach: brak reakcji Marni lub POCHWAŁA

$>$ kliknięcie NOT MATCH przy różnych literach: brak reakcji Marni

$>$ kliknięcie MATCH przy różnych literach: WYJAŚNIENIA NEGATYWNE

$>$ kliknięcie NOT MATCH przy tożsamych literach: WYJAŚNIENIA POZYTYWNE

Jak wspomniano wcześniej, dwie pierwsze odpowiedzi są uznawane przez program za prawidłowe. Mimo to, POCHWAŁA nie zawsze pada po tych ruchach dialogowych dziecka. Jeśli uczeń odkrywa kolejne karty i wie czy odkryte litery pasują do siebie czy nie, to zostanie pochwalone na zakończenie ćwiczenia. WYJAŚNIENIE NEGATYWNE w trzeciej sytuacji służy upomnieniu dziecka, po czym odkryte przezeń karty zostają z powrotem zakryte. Dziecko musi się zorientować, że należy wybrać inną parę liter (kliknąć i odkryć inne karty).

Najciekawsza jest ostatnia sytuacja: kliknięcie NOT MATCH przy tożsamych literach świadczy o tym, że dziecko nie zauważyło, że litery pasują do siebie. W przeprowadzonych badaniach zdarzało to się bardzo rzadko (patrz tabele 5 i 6), gdyż litery są wczesnoszkolnym dzieciom już raczej znane. Ważne jest jednak to, co Marni robi, gdy okaże się, że dziecko wybrało pasujące do siebie litery (lub inne jednostki w innym ćwiczeniu), a nie dało odpowiedzi MATCH. Wówczas Wirtualna Nauczycielka wyjaśnia, że trafione litery pasują do siebie wyraźnie akcentując słowo match i zachęca dziecko by spróbowało raz jeszcze (try again). Na ekranie przycisk NOT MATCH już nie jest aktywny, dziecko może nacisnąć tylko MATCH. Gdy to zrobi, Marni wygłosi jedną z POCHWAŁ. Ten etap ćwiczeń, choć w przeprowadzonych badaniach najrzadszy, jest jednym $\mathrm{z}$ ważniejszych. To w tym momencie uczeń mający specyficzne problemy z czytaniem spotyka się z aktywną pomocą Wirtualnej Nauczycielki, co jest niezbędne nawet w tak prostym ćwiczeniu jak dopasowywanie liter. Stąd też przyjęta w niniejszym opisie nazwa WYJAŚNIENIE POZYTYWNE.

Sekwencje klikania w karty (odkrywanie liter) i przyciski MATCH lub NOT MATCH oraz reakcje Marni powtarzają się, aż wszystkie karty zostaną odkryte, a uczeń ustali trzy pary liter (tożsamych lub pary małej i wielkiej litery). Na końcu ćwiczenia dziecko może jeszcze odsłuchać każdą z nazw liter klikając na jedną z nich (dopasowane litery wyświetlają się pod przyciskami MATCH i NOT MATCH). Wykonanie ćwiczenia jest nagradzane wirtualnym prezentem. 


\section{Zakończenie}

Nauka i nauczanie czytania w języku obcym wspomagane przez komputer stwarza zupełnie nowe możliwości, o których ten artykuł mówi tylko częściowo. Opisano wybrane ćwiczenia programu CLT i wyniki badań przeprowadzonych na skromnej grupie dzieci polskiej szkoły podstawowej. Celem głównym tak szczegółowego opisu nie było jednak udowodnianie, że prezentowany program stanowi najlepszy z dostępnych, choć jego twórcy niejednokrotnie tak sądzą. Program CLT wymaga jeszcze wielu poprawek, testów i prac zanim mógłby trafić do polskich szkół, gdzie byłby rzeczywiście sprawdzony przez setki dzieci uczących się czytać w języku angielskim. Dlatego wyniki przeprowadzonych przez autora badań nie koncentrują się na dokładnym oszacowaniu skuteczności metod nauczania czytania zaimplementowanych w CLT. Jednakże można śmiało postawić hipotezę, że jest to bardzo dobra propozycja, zarówno dla dzieci, jak i dla badających procesy nauczania czytania oraz komunikacji dziecko-komputer.

Dzieci polubiły „klikanie w litery” i zaprzyjaźniły się z Marni. Na pewno przekonały się, że komputer może ich czegoś nauczyć i być może jest to nawet nauka przyjemniejsza niż ta, znana im ze szkolnej ławki. Im wcześniej nauczą się dialogu z komputerem, oswoją się z tą maszyną, tym łatwiej i będzie im używać komputera w przyszłości - jako narzędzia do nauki i pracy, a także do nawiązywania i utrzymywania kontaktów $\mathrm{z}$ najbliższymi $\mathrm{i}$ znajomymi, a nie tylko do rozrywki. Podczas interakcji z programem CLT mogą się również przekonać o tym, co umieją, a czego jeszcze powinny się nauczyć. I co ważne, dzięki MLE proces nauczania nie polega na wykonywaniu kolejnych ćwiczeń wg jakiejś ogólnej listy, lecz jest dostosowywany na bieżąco, indywidualnie do danego dziecka. Dzięki temu dziecko uczy się eksperymentować, testuje własne hipotezy dotyczące zależności językowych związanych z czytaniem krok po kroku. Marni jest cierpliwą i wyrozumiałą nauczycielką, gotową zawsze pomóc, wyjaśnić popełniony błąd, podpowiedzieć prawidłową odpowiedź i wreszcie pochwalić, a nawet wynagrodzić. Tak zmotywowane dzieci do zabawy i nauki nie traktują Marni jako awatara, wirtualnego wcielenia nauczycielki, lecz jako tutora (Schaffer 2005). Kontakt z Marni pozwala im na odkrywanie możliwości ich umysłu, aktywnego rozwoju językowego i poznawczego. Jednocześnie wchodzą w nowe interakcje symboliczne, doskonalą kompetencje komunikacyjne i językowe, zwłaszcza w zakresie języka obcego (angielskiego). Wreszcie, w rezultacie tych wszystkich działań, uczą się czytać.

Dla badaczy program CLT jest bardzo dobrą propozycją dzięki rozłożeniu nauczania czytania na ćwiczenie elementarnych umiejętności metajęzykowych rozwijających świadomość fonologiczną, procesy pamięci i uwagi oraz sam język. Otrzymujemy narzędzie do modelowania procesu nauczania czytania z możliwością jego podglądu (system kontroli MLE). Nauka czytania może być realizowana przez zabawę, a zabawa może stanowić kontrolowany eksperyment. O potrzebie takiego podejścia do badań zabawy dzieci wspomina Elkonin:

„Jeszcze za życia L. S. Wygotskiego stało się jasne, że w badaniach zabawy niezbędne jest przejście do eksperymentalnego jej poznawania. Eksperymentowanie nad całą zabawą oraz poszczególnymi jej strukturalnymi elementami jest sprawą bardzo złożoną. Wymaga bowiem ono aktywnego wkroczenia w tok zabawy, a zabawa przy takim wkroczeniu latwo ulega rozbiciu." (Elkonin 1984)

Colorado Literacy Tutor dzięki wcieleniu idei Wygotskiego (strefy najbliższego rozwoju) i możliwości kontroli Managed Learning Environment oraz innym licznym rozwiązaniom jest przykładem oprogramowania edukacyjnego, który wskazuje nowy, dobry kierunek. Jest to nowy kierunek zarówno w dziedzinie samego nauczania czytania i języka obcego, jak i w badaniach nad tymi procesami. Jest także kontynuacją wizji Wygotskiego, wg którego rozwój językowy i poznawczy odbywa się w interakcji z innymi i w kontekście kulturowym. Kultura w wizji Wygotskiego stwarza określone formy zachowania, w których przygotowujemy i wykorzystujemy narzędzia - „,́rodki pomocnicze”. Te z kolei służą człowiekowi do regulacji własnego zachowania się zgodnie z celami, jakie sam sobie stawia. Wśród takich narzędzi - „środków pomocniczych” Wygotski widział język, pismo, systemy liczenia, sztukę i środki mnemotechniczne i określał je wspólnym mianem znaku. Są to narzędzia psychologiczne umożliwiające rozumienie rzeczywistości i ludzkiego zachowania, a kierowanie nim Wygotsky nazywał to signifikacją. 
Współcześnie do narzędzi psychologicznych - znaków Wygotskiego należy także zaliczyć komputer, który stał się już częścią naszej kultury. Badania interakcji człowiek (dziecko)komputer realizowanej na przykład $\mathrm{w}$ programie CLT eksplorują proces uspołeczniania komputerów, włączania ich do życia społecznego, którego produktem, wg Wygotskiego, jest kultura. Wreszcie znak Wygotskiego jest pierwotnie środkiem społecznej więzi, środkiem oddziaływania na innych, a dopiero później staje się środkiem oddziaływania na siebie samego (Wołoszynowa 1984). 


\section{Bibliografia}

Bogacka, Anna, Katarzyna Dziubalska-Kołaczyk, David Pietrala, Mikołaj Wypych, and Grzegorz Krynicki. 2006. General and Task-Specific Corpus Resources for Polish Adult earners of English. Proceedings of the LREC 2006 Conference.

Bogdanowicz, Marta. 2005. Ryzyko dysleksji. Gdańsk: Wydawnictwo Harmonia.

Dziubalska-Kołaczyk, Katarzyna, Anna Bogacka, David Pietrala, Mikołaj Wypych, and Grzegorz Krynicki. 2006. PELT: An English language tutorial system for Polish speakers. Proceedings of the MultiLing Conference.

Elkonin, D. B. 1984. Psychologia zabawy. Warszawa: Wydawnictwa Szkolne i Pedagogiczne.

Hall, Robert A. 1966. Sound and spelling in English. Philadelphia: Chilton Books.

Juszczyk, Konrad. 2005. Colorado Literacy Tutor jako pomoc w nauce i doskonaleniu czytania w języku angielskim dla polskich dzieci. Investigationes Linguisticae XII:44-61.

Kamińska, K. 1999. Nauka czytania dzieci w wieku przedszkolnym. Warszawa: Wydawnictwa Szkolne i Pedagogiczne SA. Pamuła, M. 2003. Metodyka nauczania języków obcych w ksztatceniu zintegrowanym. Warszawa: Fraszka Edukacyjna.

Pea, Roy D. 1985. Integrating Computer and Human Intelligence. [w:] Children and Computers, E. L. Klein. (red.) San Francisco: Jossey-Bass.

Pont, Beatriz, and Patrick Werquin. 2000. Literacy in a thousand words. OECD Observer 223:49-50.

Reeves, Byron, and Clifford Nass. 2000. Media i ludzie. Warszawa: PIW.

Rocławski, Bronisław. [brak]. Klocki LOGO. do zabawy i nauki wymowy, czytania, pisania, ortografii i matematyki Gdańsk: Biblioteczka Pedagogiczna - Glottispol Gdańsk.

Schaffer, Rudolph. 2005. Psychologia dziecka. Warszawa: Wydawnictwo Naukowe PWN.

Smith, Alexandra. 2006. Schools to use phonics to teach reading. The Guardian, March 202006.

Wise, B.; Cole, R.; van Vuuren, S.; Schwartz, S.; Snyder, L.; Ngampatipatpong, N.; Tuantranont, J.; \& Pellom, B. [w druku]. Learning to Read with a Virtual Tutor: Foundations Literacy. [w:] Interactive Literacy Education. Mahwah, NJ: Lawrence Erlbaum. [@:] http://cslr.colorado.edu/beginweb/virtual_tutor/virtual_tutor.html Wolf, Maryanne, Frank Vellutino, and Jean Berko Gleason. 2005. Psycholingwistyczna analiza czynności czytania. [w:] Psycholingwistyka, J. B. Gleason and N. B. Ratner. (red.) Gdańsk: Gdańskie Wydawnictwo Psychologiczne.

Wołoszynowa, Lidia. 1984. Przedmowa. [w:] Psychologia zabawy, D. B. Elkonin. (red.) Warszawa: Wydawnictwa Szkolne i Pedagogiczne. 